\title{
The effectiveness of the continuous underway fish egg sampler compared with standard vertical plankton hauls for sampling the eggs of demersal species in the southern North Sea
}

\author{
S. Lelièvre ${ }^{1, *}$, S. $\operatorname{Vaz}^{1, *}$, C. Fox ${ }^{2}$ \\ ${ }^{1}$ Department Halieutiques Ressources, IFREMER French Research Institute for Exploitation of the Sea, \\ Boulogne sur Mer, France \\ ${ }^{2}$ Scottish Association for Marine Science, Scottish Marine Institute, Oban, UK \\ *: Corresponding author : S. Lelièvre, S. Vaz, email address : stephanie.lelievre@ifremer.fr, \\ sandrine.vaz@ifremer.fr
}

\begin{abstract}
:
To date, the continuous underway fish egg sampler (CUFES) has been used primarily to map the spawning areas of pelagic fish in upwelling regions. To assess its utility in mapping the spawning grounds of demersal species, species composition and densities of eggs collected by CUFES were compared with results obtained from ring-net samples (VET: vertical egg trawl) from the southern North Sea over three annual cruises conducted in January/February. CUFES collected slightly fewer eggs per unit volume of water filtered when compared with vertically integrated samples but maps of egg distributions from both devices showed broadly similar patterns. Geostatistical analyses revealed that small-scale variability was greater with CUFES than with VET. CUFES may thus be able to resolve finer spatial structuring of egg distributions. At the sampling station scale, species compositions (in terms of proportion and abundance) from both approaches were similar, with the notable exception of flounder, which was much more abundant in CUFES samples; these results were similar when considering early and older stage eggs. Results from regression modelling showed that it was difficult to estimate total egg abundance in the water column from CUFES data with linear regression techniques even when additional factors which affect the vertical distribution of the eggs, such as depth, bedstress and wind-induced mixing, were included. CUFES therefore provides a suitable method for mapping egg distributions of the main fish species producing planktonic eggs during the winter and early spring season in the southern North Sea but may not be used easily when absolute measures of egg production are required. However, CUFES can be added to standard trawl surveys with little disruption to the baseline ground-fish survey.
\end{abstract}

Keywords: continuous underway fish egg sampler; CUFES; fish eggs; generalized linear model; spatial distribution; vertical egg trawl 


\section{Introduction}

Monitoring fish spawning grounds has been recommended as one element of an ecosystem-based approach to marine management (Scientific Expert Committee for the Fifth International Conference on the Protection of the North Sea, 2002) since spawning can be adversely affected by stock depletion, habitat disturbance, climate change and other factors (Begg and Marteinsdóttir, 2002; Rjinsdorp et al., 2009). Knowledge of the locations and extent of fish spawning areas is also required for environmental risk assessment of developments such as offshore energy (Stelzenmüller et al., 2010). The location and timing of fish spawning can be based on data from a variety of sources, including the presence of mature fish in trawl surveys (Hedger et al., 2004) and for some species acoustic detection of calls made during courtship (Širović et al., 2009; Hawkins et al., 2002). For species producing pelagic eggs, plankton surveys provide another useful approach (Checkley et al., 1997; Fox et al., 2008). Because eggs will be dispersed away from spawning sites, it is desirable to identify the eggs to species at their earliest developmental stages. Although many eggs can be visually identified based on their appearance (size and shape), and the presence of features such as oil globules, this is not possible for all species. Recent advances in the application of molecular genetics have largely overcome this limitation although the costs of such techniques remain an obstacle to its widespread application to plankton samples (Fox et al., 2008; Goodsir et al., 2008). Pelagic fish eggs are often highly spatially aggregated (Checkley et al., 1997;Munk et al., 2009) and it is difficult to capture this variability using standard trawl or plankton surveys where inter-station distances are typically of the order of tens of $\mathrm{km}$. Detecting such fine-scale structuring is particularly relevant when examining links between egg distributions and oceanographic features such as fronts (Munk et al., 2009) and up-welling zones (Bakun, 1996). In addition, it is often difficult to incorporate dedicated plankton sampling into standard fisheries-research trawl surveys due to constraints on ship time. To address these problems Checkley et al. (1997) introduced the Continuous Underway Fish Egg Sampler (CUFES) which consists of a sub-surface intake, pump and separator which can be operated continuously as the ship steams. CUFES can also be coupled with continuous environmental monitoring equipment allowing simultaneous fine-scale mapping of egg distributions (Lo et al., 2001) and environmental parameters such as water temperature and chlorophyll (Checkley et al., 2000). CUFES has been widely used to map the distribution of eggs of pelagic species such as Pacific sardine (Lo et al., 2001) and European anchovy (Petitgas et al., 2006) but because the intake is at a fixed depth ( $5 \mathrm{~m}$ depth) there are concerns about the use of CUFES to estimate total egg abundance in the water column. Estimates of total egg abundance are required when the aim is to produce egg-based stock assessments (Lasker et al., 1985; Priede and Watson, 1993; Armstrong et al., 2001; Lo et al., 2001). Because the early developmental stages of healthy planktonic fish eggs are usually positively buoyant (Sundby, 1983; Fritsch, 2005; Coombs et al., 2004) The intake of CUFES is generally at the correct depth to sample water where the maximum egg concentration is found. However, because the depth distribution of eggs is also affected by the degree of vertical mixing, due for example to wind stress (Sundby, 1983; Petitgas et al. 2006, Combs et al., 2001), the proportion of total eggs collected by CUFES will not be constant over time. The buoyancy of eggs can also change as they develop and this can lead to marked changes in their vertical distribution (Page et al., 1989, Combs et al, 2001, Combs et al, 2004, Dopolo et al, 2005, Pépin et al, 2005).

In recent years there have been increasing calls for fisheries-research trawl surveys to collect additional information but because of staff and time constraints this has proven difficult. The addition of automated sampling devices such as ferry-boxes (Holley and Hydes, 2002) and semi-automated sampling methods, such as CUFES, could provide valuable additional data without compromising the core surveys (Lo et al., 2001). In this paper we describe an application of CUFES in the Eastern English Channel and the 
southern part of the North Sea, during the French component of the International Bottom Trawl Surveys (IBTS) from January to February 2006 to 2008. This survey coincides with the onset of spawning of many North Sea fish species (Taylor et al., 2007). We compared results from CUFES with those from conventional depth-integrated plankton sampling in terms of the relative proportions of eggs of different taxa in the samples and the utility of the data for producing maps of spawning areas. Finally we consider whether CUFES data can be used to estimate total egg abundance in the water column by incorporating additional environmental variables such as wind-speed (Curtis et al, 2007) and water depth (Pépin et al., 2005; Van Der Lingen et al., 1998; Checkley et al., 1997).

\section{Methods}

\section{Data collection}

All samples were collected during the French IBTS conducted between January and February 2006 to 2008 using the RV "Thalassa". The protocols for the standard trawl hauls are described in the IBTS Working Group documents (ICES, 2004) and are not considered further here. Physical oceanographic data were collected at several supplementary hydrological stations using a SBE 19 SEACAT Profiler. For the collection of fish eggs, CUFES was run continuously during the survey. The intake for the CUFES was located at a depth of five meters and the concentrator sieve and collector had a mesh size of $500 \mu \mathrm{m}$. Flow rate was recorded every 30s at the CUFES out-take. A sample was collected from the CUFES every $30 \mathrm{~min}$ (corresponding to about $20 \mathrm{~m}^{3}$ seawater and a distance ranging from 0 to $7 \mathrm{~km}$ depending on ship speed). In 2006 and 2007, a simple cylindro-conical plankton net (mouth opening diameter of $0.6 \mathrm{~m}, 2.6$ $\mathrm{m}$ deep and $500 \mu \mathrm{m}$ mesh) was used to collect additional vertical egg trawl samples (VET). In 2008, a WP2 plankton net was used (mouth opening diameter of 0.55 meters, $2.7 \mathrm{~m}$ deep, $500 \mu \mathrm{m}$ mesh). These nets were deployed from the surface to within $2 \mathrm{~m}$ of the sounded depth and retrieved at a speed of $1 \mathrm{~ms}^{-1}$. The volume of water filtered in each haul was estimated using a KC-Denmark digital non-reversing flowmeter installed in the net mouth. CUFES was also run whilst the ship was stationary undertaking VET hauls to allow direct comparisons to be made.

Both CUFES and VET samples were fixed in a buffered $0.9 \%$ formaldehyde in seawater (Mastail and Battaglia, 1978) and returned to the laboratory for sorting. Fish eggs were identified on the basis of size and the presence of oil globules or other distinguishing features and staged based on the degree of embryo development (Russell, 1976; Munk and Nielsen, 2005; Lelièvre, 2007). Eggs were assigned to one of two developmental stages: stage 1, without embryo, corresponding to stages IA and IB after Thompson and Riley (1981) and stage 2 with an embryo, corresponding to stage II, III, IV and V after Thompson and Riley (1981).

Visual identification to species is impossible for early stage eggs of some groups of fish e.g. dab and flounder or cod, haddock and whiting (Taylor et al., 2002). For these problematic eggs, information on the co-occurrence of later stage eggs in the samples and/or the presence of adult fish in the nearest trawl catches were used to guide egg identification. Although some uncertainty may arise from such methodology, this enabled all eggs, except for the rocklings, to be assigned to species.

Numbers of eggs of each identified taxa were converted into number of eggs (Nstd) for a standard reference volume of $20 \mathrm{~m}^{3}$ (approximating the water volume filtered by the CUFES in $30 \mathrm{~min}$ ) using equation 1.

$$
\mathrm{Nstd}=\mathrm{N} / \mathrm{Vf} \times 20
$$

where $\mathrm{N}=$ number of eggs in taxa and stage; $\mathrm{V}=$ filtered volume $\left(\mathrm{m}^{3}\right)$. 
Further data analysis was undertaken using geostatistics and statistical modelling of the relationship between egg abundances in the CUFES and VET samples.

\section{Spatial pattern and geostatistical analyses}

Fish egg distributions were initially reviewed for each species and developmental stage using bubble plots. Geostatistical analyses were then performed (Webster and Oliver, 2001). Egg densities for each taxa were initially log-transformed $\left(\log _{10}(x+1)\right.$ and the distance between samples calculated using latitude and corrected longitude (longitude $\times \cos (($ latitude $\times \pi) / 180)$ ). Local trends violate the assumption of the random function model on which the geostatistical analyses are based. Spatial trends, when present, were therefore modelled by fitting a low-order polynomial (linear or quadratic regression) of the spatial coordinates to the egg density data using the least-squares regression method. However, long range trend surface removal affects estimation of local spatial structure as their conjugated effects on the observed value may be difficult to separate (Berke, 1999). Therefore, only if the fitted polynomial accounted for over $30 \%$ of the variance was the experimental variogram calculated on the trend regression residuals; otherwise the raw data were used. This threshold was chosen empirically as a compromise to both prevent violation of the random function model assumption and preserve local structures in the data that may be potentially inter-twined with long range trends. Theoretical models (exponential, circular, spherical and pentaspherical) were fitted to the experimental variogram by least-squares regression to determine the nugget, sill and range parameters. The model with the best visual and statistical fit was retained as the theoretical variogram.

Range was taken as an estimate of the average diameter of egg patches (Webster and Oliver 2001) and Q, the amount of spatial structuring (i.e. the proportion of data variability) explained by the variogram was estimated as the variance attributable to spatial dependence (C) divided by the sill variance (i.e. the maximum variance in the data calculated as the sum $\left(C+C_{0}\right), C_{0}$ being the nugget variance). The nugget is the amount of variance not explained by the spatial model as a consequence of variation at distances smaller than the sampling interval. For the purpose of spatial pattern comparison between VET and CUFES samples, the same model was retained for both types of data and was chosen on the basis of the one with the highest joint fit.

Finally, ordinary or universal kriging was used to generate continuous maps of the egg distribution patterns for selected species. However, sampling locations differed between years as the track of the fisheries survey is not constant from year to year due to operational constraints. In order to eliminate any potential effect on the interpolation, a preliminary data exploration was conducted to identify a set of suitable interpolation parameters across all years. This analysis consisted of resampling a given continuous map using the four different sampling designs and evaluating and comparing the effect of different kriging parameters on the re-interpolation of this known property.

The average distance between nearby pairs of observations, corresponding to the survey resolution, was 0.25 decimal degree of latitude (around $21.9 \mathrm{~km}$ ). This was used to set the interpolation grid size (resolution). The search radius of nearby values was set to 0.5 (i.e. twice the average separation distance between transects) and the number of neighbours used was taken between a set minimum of five and maximum of fifteen data points. Geostatistical analyses were undertaken using Genstat (GenStat Release 7.1., 2004).

\section{Comparison between CUFES and depth-integrated plankton hauls}

In order to measure the representativeness of each species in each sampling device, the occurrence frequency, relative proportions and absolute densities of eggs by taxa and 
stage were compared between the CUFES and VET samples collected whilst the ship was stationary (Fig. 1).

\section{Predicting depth-integrated egg densities from CUFES data}

Egg data from both devices were log-transformed $\left(\log _{10}(x+1)\right)$ and the relationship between egg density in CUFES and vertical plankton samples modelled using GLMs (Generalised Linear Models). As is typical for ichthyoplankton data, there were a large number of zero values; therefore the data were modelled using a two-step approach. First, presence/absence was modelled using a binomial GLM with a logit link. Second, non-zero log-transformed egg densities were modelled using a gaussian GLM with a canonical link. This approach is suitable for zero inflated count data, especially when different processes are suspected to underlie presence/absence and density (Stefansson, 1996). Available co-variables which might affect fish egg vertical distributions were depth, bedstress and wind speed. Depth $(\mathrm{m})$ and wind speed $(\mathrm{kt})$ measurement were continuously recorded by the vessel sensors. In most instances vertical diffusivity is related to the square of wind speed (Curtis et al. 2007) and we incorporated this variable in our models using a second order polynomial. Bedstress is a measure of the shear friction of water on the seabed caused by the tidal current (expressed in $\mathrm{N} \mathrm{m}^{-2}$ ). Bedstress was estimated using a two-dimensional hydrodynamic model (Aldridge and Davies, 1993) maintained by the Proudman Oceanographic Laboratory (UK). Bedstress and water depth were log-transformed (stressT and depthT) to improve the linearity of their relationship with egg density. The inverse of depth (1/depthT) was computed, as generally there is an inverse relationship between depth and egg densities. Model predictors were selected using the Akaike Information criterion (AIC, Sakamoto et al, 1986). Having obtained fitted values for the probability, $p$, of a nonzero sample, and for the expected value of log (VETdensities +1$), \hat{y}$, conditional on it being positive, the predicted unconditional egg densities are given by py. The combination of these two model predictions is referred to as the delta model. To evaluate overall model performance, Spearman correlations and Wilcoxon tests were used to compare observed and predicted VET densities for each species. The Wilcoxon signedrank test is a non-parametric hypothesis test for the case of two related samples or repeated measurements on a single sample. It can be used as an alternative to the paired Student's t-test when the population cannot be assumed to be normally distributed (Wilcoxon, 1945).

The adjusted coefficient of determination of the model (adjusted $\mathrm{R}^{2}$ ) was computed to assess the predictive power of the delta model. It was used to measure the proportion of variance explained by the final model and provides a measure of how well future outcomes are likely to be predicted by the model. This coefficient of determination has the advantage of taking into account the respective numbers of degrees of freedom in the observations and explanatory parameters. Statistical analyses were undertaken using $R$ 2.2.1 (R Development Core Team, 2005). 


\section{Results}

\section{Oceanography}

Supplementary hydrological stations were conducted during the IBTS and were examined. CTD profiles revealed that the water at most stations was vertically mixed with little or no thermal stratification (Table 1). In some locations there was evidence of a salinity gradient, particularly for locations close to areas of riverine input although the IBTS survey does not go into the estuaries themselves. Available physical data are summarised in Figure 2. Most of the study area is shallow although some samples were collected in water deeper than $50 \mathrm{~m}$ in the north-western corner (Fig. 2a). Observed wind speeds varied between 1 and 34 knots depending on location and years (Fig. 2b-d). In 2008 (Fig. 2d), there was relatively little wind in the north-eastern part of the study area. However, the resulting stratification was very weak. Modelled bedstress was highest in the Dover Straits and off the East Anglian coast.

\section{Fish eggs}

VET and CUFES samples were collected whilst the vessel was stationary at the locations shown in figure 1. In total 66 vertical plankton tows were undertaken in 2006, 68 in 2007 and 140 in 2008 (total 274). During the IBTS, CUFES ran continuously and 947 samples were collected in 2006, 878 in 2007 and 1,050 in 2008. Figure 3 shows the trajectory of the research vessel during the IBTS from 2006 to 2008 and the centre points of the underway CUFES samples. CUFES flow rates varied between 500 to $800 \mathrm{I}^{\mathrm{min}} \mathrm{m}^{-1}$. VET filtered volumes varied from 1 to $67 \mathrm{~m}^{3}$ depending on sampling depth and local currents. Eggs of dab (Limanda Limanda), plaice (Pleuronectes platessa), cod (Gadus morhua), flounder (Platichtys flesus), whiting (Merlangius merlangus), rocklings (Lotidae) and longrough dab (Hippoglossoides platessoides) were common. Eggs of other species including common sole (Solea solea), Callionymus sp., solenette (Buglossidium luteum) and brill (Scophthalmus rhombus) were found occasionally.

\section{Fish egg distributions}

Dab (Limanda limanda) was the most abundant and frequent species found in both VET and CUFES samples. A comparison of the initial maps based on CUFES and VET data for all years (Fig. 4) indicates that the distribution pattern of dab eggs (all stages combined) was similar. Both VET and CUFES sampling showed that dab eggs were widely distributed in the central and eastern parts of the study area, from the English Channel to the German Bight but were less common in deeper water off the northeastern coast of England. Cod (Fig. 5) and plaice (Fig. 6) were the next most abundant species. Distribution patterns for each separate year were, like dab, fairly similar each year and only the aggregate data are presented here. Cod and plaice egg distributions were similar using both CUFES and VET data although overall egg densities were lower than for dab. Whether early or later stages of eggs were considered, the distribution appeared to be fairly similar in both devices but there were more samples with zero eggs using the CUFES. This was particularly noticeable in the German Bight.

\section{Geostatistical analyses}

Variogram parameters for data collected when the vessel was stationary are presented for each of the main species in Table 2. The presence of spatial trends or drifts was 
explored before each geostatistical analysis and, if this percentage exceeded $30 \%$, the same amount of trend was generally observed for a given species in data from both the CUFES and VET. For cod in 2006 in both sampling devices the variograms appeared completely unstructured with no obvious spatial dependency and only a nugget variance could be estimated ("pure nugget"). Finally the amount of spatial structure and the range of the theorical variograms could only be compared for those variables for which no trend or the same amount of trend could be detected in both CUFES and VET datasets and if the same variogram model was used. Generally, VET sampling could explain a larger amount of spatial structure than CUFES indicating that egg densities were more variable at small distances. However, the ranges determined from CUFES samples were generally similar or lower than those determined from VET samples. This indicated equivalent or slightly smaller patch sizes from CUFES than would be inferred from VET data.

Underway CUFES sampling resulted in a very large number of samples which greatly increased the spatial resolution (Fig. 3). The interpolated (kriged) distribution of dab eggs for underway CUFES data showed little variation between years (Fig. 7). The inter-annual variability map, computed as the local standard deviation divided by the maximum density value ever observed showed that the variability was always below $27 \%$ and mostly located in areas of high egg abundance.

Similarly, interpolated maps by year for other species showed no major differences between years and amalgamated maps for cod (Fig. 8a) and plaice (Fig. 8b) are presented. Both cod and plaice eggs were predicted to be widely distributed over the study area with higher concentrations in the central and eastern North Sea. Cod and plaice eggs were also found in the eastern Channel.

Egg distributions from stationary data (Fig. 4) showed similar distribution patterns to the kriged maps of the underway data. However, the larger number of samples collected by the underway CUFES revealed finer spatial detail than could be achieved using the VET data alone.

\section{Comparison of taxa occurrence frequency of fish eggs between VET and CUFES}

With the exception of flounder, individual taxa had a higher probability of being found in VET samples compared with CUFES (Table 3) but the probability of finding rarer species (rockling sp., and American plaice) was similar in both devices. Considering developmental stages, the later developmental stages (stage 2) of a species tended to be better represented in VET samples than in CUFES.

\section{Comparison of egg densities and taxa composition between VET and CUFES}

For most species except flounder, the number of eggs sampled per volume of water was slightly higher in VET samples than in CUFES samples (Table 4). The most abundant species represented a larger proportion of the catch in VET than in CUFES samples. The proportions were similar in both devices for rocklings and American plaice eggs, but higher proportion of flounder eggs were found in CUFES. For most species, early stage eggs were as or more abundant than later stages in both devices with the exception of plaice for which later stage eggs were more abundant.

\section{Predicting the densities of eggs in VET samples from CUFES data}

The density of eggs (all species and stages) in VET samples was linearly related to those in the CUFES samples although there was considerable scatter (Fig. 9). This suggests that linear models (GLM) might be used to estimate egg densities over the whole water column (assuming that the VET acts as a 100\% efficient sampling device) as a function of near-surface egg densities (CUFES) if the incorporation of additional parameters such as 
wind, wind ${ }^{2}$, bedstress and the inverse of the depth reduces the variance about the mean regression (Fig. 10).

Modelling was undertaken for the main species found, namely dab, cod, plaice, flounder, American plaice and rockling. Bedstress and to a lesser extent wind speed had an adverse effect on the probability of presence over all the water column of some species relative to surface samples (Table 5). However, the inverse of the depth seemed to have a positive effect on the probability of presence of eggs (mainly for flatfishes). Therefore shallow waters, low wind speed and bedstress may increase the occurrence of eggs over all the water column relative to surface samples. These effects however are variable among species. In the conditional-abundance models (Table 6), wind speed and bedstress did not have a significant effect on most species egg densities over all the water column. The inclusion of the inverse of depth however, improved the relation between egg counts from CUFES and VET samples.

The gaussian models had higher adjusted $\mathrm{R}^{2}$ than the binomial models suggesting that it may be possible to model the non-zero densities using simple regression techniques (Fig. 9) but modelling the abundance, including the zero counts is more challenging. The results of comparing the delta model predictions with observed VET values are shown in Table 7. For all species there was a highly significant correlation between observed and predicted values. However, the Wilcoxon rank tests showed that, apart from flounder, there was a significant difference between the means of VET observation and prediction. This represents a significant bias such that the delta GLM model cannot accurately reproduce total abundance from surface samples, even with the incorporation of hydrographical co-variables.

\section{Discussion}

CUFES has mainly been used for mapping the spawning areas of pelagic species such as sprat although, in theory, it could be used with any species producing planktonic eggs (Pépin et al., 2005). In order to evaluate the utility of CUFES for the conditions and species found in the southern North Sea, this study aimed to compare results from CUFES with those from conventional, depth-integrated plankton sampling. Because the intake of the CUFES is at a fixed depth close to the sea surface, its sampling efficiency is affected by multiple inter-acting factors including the depth at which the fish spawn, changes in egg buoyancy with development and water column conditions.

There are few reports of natural spawning behaviour of fishes and most of our knowledge has come from studies on captive fish. Several species are known to spawn near the surface. For example, Baynes (1994) observed tank-reared sole swimming to the surface to spawn, and there are anecdotal reports of sole spawning at the surface at night in the wild. Borremans (1987) concluded that sole spawn around shallow $(<30 \mathrm{~m})$ sandbanks and buoyant eggs would probably still reach the surface relatively quickly. However, other species are thought to spawn in mid-water. Acoustic observations of cod spawning columns in western Atlantic suggested that the fish were spawning at $75 \mathrm{~m}$ off the bottom when total water depth was $350 \mathrm{~m}$ (Rose, 1993).

Healthy pelagic fish eggs are generally positively buoyant and under calm conditions are expected to accumulate close to the surface (Ådlandsvik et al., 2001; Conway et al., 1997). The vertical profile of egg abundance often follows an exponential-decay model (Pépin et al., 2005) but under conditions of wind stress eggs will be mixed down in the water column which can lead to a sub-surface peak in abundance. Given data on egg size, buoyancy and wind-stress it is sometimes possible to produce reasonably accurate predictions of the vertical distribution of fish eggs assuming steady-state conditions (Sundby, 1983; Pépin et al, 2005). However, the buoyancy of individual eggs can vary with parental history (Pépin et al. 2005) and experimental work on egg buoyancy has only been conducted on a limited range of species. 
Vertical egg distributions with sub-surface peaks are not uncommon. Coombs et al. (1985) reported that the highest concentrations of sprat eggs were found just above the thermocline at 20-30 m depth in the western English Channel. Strongly stratified water columns often appear to be associated with sub-surface egg maxima (Coombs et al., 1985; Ouellet et al., 1997; Pépin et al., 2005), under which conditions CUFES may not sample efficiently. The water column in the southern North Sea during winter and spring is generally well mixed due to strong tidal action (CTD observations in this study and Fox et al., 2005; Radach et al., 1993; Lund-Hansen et al, 1996) although salinity stratification can occur close to the coasts (Munk et al., 2009). Under these generally mixed conditions, CUFES may be a suitable tool for mapping pelagic fish egg distributions.

In the present study, the probability of finding a species was higher in VET samples compared with CUFES. This could reflect vertical distribution patterns but might also relate to the total volumes of water sampled by the two gears (CUFES approx. $20 \mathrm{~m}^{3}$ per sample compared with VET up to $67 \mathrm{~m}^{3}$ per sample). Nevertheless, differences in sampling efficiency between the two gears were not large enough to unduly influence distribution maps. If the aim of a survey is to assess ichthyoplankton biodiversity or to map the distribution of rare species complementary sampling using both gears could be recommended (Checkley et al., 2000; Pépin et al., 2005).

Comparison of the relative proportions of eggs of different taxa in CUFES and VET samples from the southern North Sea also showed similar species composition although flounder and dab were better represented in CUFES and VET respectively. This could be the result of either positive egg buoyancy or a near-surface spawning behaviour of flounder.

Pépin et al. (2005), studying American plaice, and Ouellet et al. (1997), studying cod reported that stage 1 eggs were more abundant at depth $(40 \mathrm{~m})$ relative to later stages. Lo et al. (2001), studying sardine, also found similar results. This was not apparent in our study where both early and later developmental stages were equally represented in VET (depth integrated) and CUFES (surface) samples such as Zwolinski et al., 2004 and Checkley et al., 1997. The relative shallowness of the southern North Sea compared with other areas such as the Gulf of St. Lawrence and the lack of thermal stratification in the southern North Sea could explain these differences.

Regardless of sampling device, there were some differences between spatial distributions of early and later stage eggs by species. Such differences would be generated by dispersal and mortality (Bunn et al., 2000). In the southern North Sea, there is a strong tendency for eggs spawned in the eastern Channel to be transported towards the Dutch coast and the German Bight by tidal and wind-driven flows (Harden et al., 1979; Bakun, 1996; Van der Veer et al., 1998; Bolle et al., 2009). Moreover, the observed patterns may be incomplete due to the survey timing (January-February). For example, this period coincides with the spawning peak for plaice (Harding et al., 1978) and cod (Blanchard et al., 2005; Heessen and Rijnsdorp, 1989) but is at the beginning of spawning for whiting and dab (Htun-Han, 1978). Dab eggs were the most abundant species found in our samples but this probably reflects their overall abundance in the North Sea rather than stage through the spawning production cycle

Geostatistical analyses, aimed at quantifying the spatial structures in the data, confirmed that the observed patterns were comparable between the two sampling gears. Nevertheless, a larger amount of spatial structure could be explained with VET sampling than CUFES indicating that CUFES samples were more variable at smaller distances than VET's. Such differences probably reflect horizontal patchiness in egg distributions but can also be generated by differences in water volumes sampled by the two gears. As noted by Pépin et al. (2005), CUFES can generate greater accuracy in mapping but has lower precision than vertically deployed plankton sampling. Although the VET samples nearly the full water column, its surface area coverage is relatively small. In contrast, CUFES integrated a large water volume from the horizontal sub-surface layer which resulted into higher sample variability. This effect may be compared to additional noise in CUFES sampling as a result of its larger surface input. From variogram parameters, the 
scale of variation of a particular variable could be determined, indicating its spatial dependence. Since the ranges determined were similar, or slightly smaller for CUFES, equivalent patch sizes can be inferred from both devices. There is therefore a trade-off between the two sampling strategies. Which is more optimal will depend on the aims of the survey.

Our results showed that the average patch size of demersal species eggs in the southern North Sea $(50-300 \mathrm{~km})$ were much larger than that reported for pelagic species such as Pacific sardine $(22 \mathrm{~km}$, Lo et al., 2001). This suggests either more diffuse spawning but could also result from different physical mixing or mortality processes operating in the two areas. The shape of the variograms also carried valuable information (Webster and Oliver, 2001). Selected circular and pentaspherical models curve less gradually than other models such as exponential models. Such variogram shapes are typical of transition features of spawning grounds with relatively precise boundary limits, which shared common extents and appeared as patches, some with large values, some with small ones.

The main advantage of CUFES is that sampling does not interfere with other ship activities and such sampling can continue, even in bad weather (Checkley et al., 2000). The large number of samples which can be collected by CUFES enhances horizontal sampling resolution and enables the production of more detailed maps of spawning grounds (Lo et al., 2001). These maps can then be used to identify recurrent, occasional or unfavourable spawning area for each species (Bellier et al., 2007).

Because egg based methods are increasingly being used to generate stock assessments, there has been great interest in whether CUFES data can be used to estimate total egg abundance in the water column (Pépin et al., 2005; Pépin et al., 2007). Models incorporating water column density and wind stress have been used to predict the vertical distribution of eggs of species such as cod (Sundby et al., 1983), anchovy and sardine (Boyra et al., 2003; Petitgas et al., 2006) sprat and blue whiting (Petitgas et al., 2006), and it should be possible to predict total egg abundance in the water column from CUFES data by incorporating suitable environmental co-variables. In the present study there was a positive and significant correlation between total egg densities found in CUFES and VET samples collected at the same location and time confirming the general proportionality between the two gears. However, Pépin et al. (2007) concluded that the increased variance in CUFES compared with Bongo net samples would lead to a significant loss in precision in estimates of egg abundance and they found that inclusion of environmental variables did not lead to any major improvement. In the present study, the addition of wind speed, bedstress and depth parameters did lead to some improvement in model fit between CUFES and VET data. As observed in previous studies (Coombs et al., 2003; Pépin et al., 2007), wind speed and bedstress had a slight effect on egg density predictions, but only for some species. Results indicated that low wind speeds combined with shallow water and low bedstress increased the probability of eggs being found in the rest of the water column rather than at the surface. In these particular conditions, typical of the German Bight during the period of study, CUFES samples had lower occurrence frequency than VET. In this area, eggs seemed to be out of reach of CUFES operating depth $(5 \mathrm{~m})$ being either closer to the surface or, on the contrary, held down at a lower depth. However, when it came to reproducing the egg density levels, only depth was truly relevant. Selected models were different for each species, showing that spawning behaviour and location as well as species specific egg buoyancy will affect relative catch ratios between CUFES and VET. Finally, the delta model failed to reproduce accurately the density levels observed in the water column. This resulted partly from the underlying binomial GLM which could not fully account for difference in occurrence frequency between both devices. Moreover, the Gaussian model tend to smooth predictions and not reproduce extremely high observations while the binomial model will generate probability of presence by taking into account absence data. As a result, the delta model will often produce lower predictions than observed as the predicted average positive densities are further reduced by the probability of presence. 
The use of non-linear modelling techniques, and in particular 1D hydrological modelling, may yield much better results (Petitgas et al., 2006) and should probably be used if the objective is to provide absolute egg density measures

\section{Conclusions}

When used in the southern North Sea, CUFES was dependable and simple to operate. Compared with vertical plankton hauls, CUFES does not require stationary sampling which saves time and may improve survey efficiency when the aim is to delineate spawning areas (Van der Lingen et al., 1998). Although our results showed that it was difficult to use CUFES data to estimate total egg abundance in the water column, CUFES can certainly be used to produce maps of spawning areas with high spatial resolution.

Such fine resolution maps are likely to be of significant benefit in relation to Environmental Impact Assessments where the spatial scales of the assessments are typically at 1-20 km scales. Fine-scale mapping may also be of value in relation to the design of marine protected areas (MPAs), where large-area closures may be unacceptable. Mapping of spawning areas has been recommended as a component of an ecosystem approach to marine management but because spawning grounds expand and contract in relation to changes in spawning stock size (and may even shift location in response to environmental change), mapping may need to be repeated periodically. Because CUFES can be integrated into existing trawl or acoustic surveys relatively easily, it may prove to be a valuable tool for monitoring programs in areas such as the North Sea.

\section{Acknowledgements}

This work was funded jointly by the Region Nord-Pas de Calais and IFREMER. We also acknowledge financial support by the EU as part of ISADO and CHARM projects (ERDF Interreg III and IVA France (Manche - Angleterre). Stéphanie Lelièvre was partly supported by a Encora travel grant in the context of the Young Professionals Exchange Program (YPEP) to fund her three months stay in the Scottish Association for Marine Science Dunstaffnage Marine Laboratory in Oban (Scotland). The authors would like to express their sincere thanks to the scientific staff and the crew of the Thalassa research vessel for their support in sampling at sea. 


\section{References}

Ådlandsvik, B., Coombs, S., Sundby, S. and Temple, G. (2001) Buoyancy and vertical distribution of eggs and larvae of blue whiting (Micromesistius poutassou): observation and modelling. Fis. Res., 50: 59-72.

Aldridge, J. N., and Davies, A. M. (1993) A high resolution three dimensional hydrodynamic tidal model of the eastern Irish Sea. Journal of Physical Oceanography, 23: $207-224$.

Armstrong, M.J., Connolly, P., Nash, R.D.M., Pawson, M.G., Alesworth, E., Coulahan, P.J., Dickey-Collas, M., Milligan, S.P., O'Neill, M., Witthames, P.R. and Woolner, L. (2001) An application of the annual egg production method to estimate spawning biomass of cod (Gadus morhua L.), plaice (Pleuronectes platessa L.) and sole (Solea solea L.) in the Irish Sea. ICES J. Mar. Sci. 58: 183-203.

Bakun, A. (1996) Patterns in the Ocean: ocean processes and marine population dynamics, California Sea Grant College, 323 pp.

Baynes, S.M., Howell, B.R., Beard, T.W., Hallam, J.D. (1994) A description of spawning behaviour of captive Dover Sole, Solea solea (L.). Netherlands Journal of Sea Research 32: 271-275.

Begg, G.A. and Marteinsdóttir, G. (2002) Environmental and stock effects on spatial distribution and abundance of mature cod Gadus morhua. Mar. Ecol. Prog. Ser. 229: 245262.

Bellier, E., Planque, B. and Petitgas, P., (2007) Historical fluctuations in spawning location of anchovy (Engraulis encrasicolus) and sardine (Sardina pilchardus) in the Bay of Biscay during 1967-73 and 2000-2004. Fish. Oceanogr., 16: 1, 1-15.

Berke, O. (1999) Estimation and prediction in the spatial linear model. Water, Air and Soil Pollution, 110: 215-237.

Blanchard JL, Heffernan OA, Fox CJ. 2005. North Sea cod. ICES Cooperative Research Report, 274, Copenhagen. 76-88

Bolle LJ, Dickey-Collas M, van Beek JKL, Erftemeijer PLA, Witte JIJ, van der Veer HW, Rijnsdorp AD (2009) Variability in transport of fish eggs and larvae. III. Effects of hydrodynamics and larval behaviour on recruitment in plaice. Mar Ecol Prog Ser 390:195211.

Borremans, C. (1987) North Sea spawning grounds of the sole (Solea solea) located from the 1984 Belgian plankton survey. Proceedings V Congress European Ichthyology, 187191.

Boyra, G., Rueda, L., Coombs, S.H., Sundby, S., Ådlandsvik, B., Santos, M. and Uriarte A. (2003) Modelling the vertical distribution of eggs of anchovy(Engraulis encrasicolus) and sardine (Sardina pilchardus). Fish. Oceanogr., 12: 381-395.

Bunn, N., Fox, C. and Webb, T. (2000) A litterature review of studies on fish egg mortality: implication for the estimation of spawning stock biomass by the annual egg production method, Science series Technical Report, 111, 37p.

Checkley, D.M., JR, Ortner, P.B., Settle, L.R., and Cummings, S.R. (1997) A continuous, underway fish egg sampler, Fish. Oceanogr, 6: 58-73.

Checkley, D.M., Hunter, J.R., Motos, L. and. Van der Lingen, C.D (eds.). (2000) Report of a workshop on the use of the Continuous Underway Fish Egg Sampler (CUFES) for mapping spawning habitats of pelagic fish. GLOBEC Report 14, $65 \mathrm{pp}$.

Conway, D.V.P., Coombs, S.H. and Smith, C. (1997) Vertical distribution of fish egg and larvae in the Irish Sea and southern North Sea, ICES J. Mar. Sci., 54: 136-147.

Coombs, S., Fosh, C. and Keen, M. (1985) The buoyancy and vertical distribution of eggs of sprat (Sprattus sprattus) and pilchard (Sardina pilchardus). J. Mar. Biol. Assoc. U.K. 65: 461-474.

Combs, S.H., Morgans, D. and Halliday, N.C. (2001) Seasonal and ontogenic changes in the vertical distribution of eggs and larvae of mackerel (Scomber scombrus L.) and horse mackerel (Trachurus trachurus L.). Fisheries Research, 50: 27-40. 
Coombs, S.H., Giovanardi, O., Halliday, N.C., Franceshini, G., Conway, D.V.P., Manzueto, L., Barrett, C.D. and Mc Fadzen, I.R.B. (2003) Wind mixing, food availability and mortality of anchovy larvae Engraulis encrasicolus in the northern Adriatic Sea. Mar. Ecol. Progr. Ser., 248: 221-235.

Coombs, S.H., Boyra, G., Rueda, L.D., Uriarte, A., Santos, M., Conway, D.V.P. and Halliday, N.C. (2004) Buoyancy measurements and vertical distribution of eggs of sardine (Sardina pilchardus) and anchovy (Engraulis encrasicolus). Mar Biol, 145, 959-970.

Curtis, K.A., Checkley, D.M.JR. and Pépin, P. (2007) Predicting the vertical profiles of anchovy (Engraulis mordax) and sardine (Sardinops sagax) eggs in the California Current System, Fish. Oceanogr., 16: 68-84.

Dopolo, M.T., Van der lingen, C.D. and Moloney, C.L. (2005) Stage-dependant vertical distribution of pelagic fish eggs on the western Agulhas Bank, South Africa. African journal of marine science, 27: 249-256.

Fox, C., Taylor, M., Dickey-Collas, M., Van Damme, C.J.G., Bolle, L., Daan, N., Rohlf, N., Kraus, G., Munk, P., Fossum, P. and Bailey, N. (2005) Initial results from the 2004 ichthyoplankton survey of the North Sea. ICES CM 2005/AA:04, 40pp.

Fox, C.J., Taylor, M., Dickey-Collas, M., Fossum, P., Kraus, G., Rohlf, N., Munk, P., van Damme, C.J.G., Bolle, L.J., Maxwell, D.L. and Wright, P.J. (2008) Mapping the spawning grounds of North Sea cod (Gadus morhua) by direct and indirect means. Proc. R. Soc. B, 275: 1543-1548.

Fritsch, M. (2005) Traits biologiques et exploitation du bar commun Dicentrarchus labrax (L.) dans les pêcheries françaises de la Manche et du Golfe de Gascogne. Mémoire de thèse, Ifremer, 314pp.

GenStat Release 7.1, Copyright (2004) Lawes Agricultural Trust (Rothamsted Experimental Station). Payne, R.W., Hardings, S.A, Maurray, D.A., Soutar, D.M., Baird, D.B., Welham, S.J., Kane, A.F., Gilmour, A.R., Thompson, R., Webster, R. and Tunnicliffe Wilson, G. VSN International, Wilkinson House, Jordan Hill Road, Oxford, UK. Goodsir, F., Armstrong, M.J., Witthames, P.R., Maxwell, D.L. and Fox, C.J. (2008) The use of species-specific TaqMan probes for identifying early stage gadoid eggs following formaldehyde fixation. ICES J. Mar. Res. 65: 1573-1577.

Harden, J. F.R., Arnold, G.P., Greer, W.M. and Schloes, P. (1979) Selective tidal stream transport and the migration of plaice (Pleuronectes platessa L.) in the southern North sea, J. Cons. int. Explor. Mer, 38: 331-337.

Harding, D., Nichols, J.H., and Tungate, D.S. (1978) The spawning of plaice (Pleuronectes platessa L.) in the southern North Sea and English Channel. Rapports et Procès-Verbaux des Réunions du Conseil International pour l'Exploration de la Mer, 172: 102-113.

Hawkins, A.D., Casaretto, L., Picciulin, M. and Olsen, K. (2002) Locating spawning haddock by means of sound. Bioacoutics 12: 284-286.

Hedger, R., McKenzie, E., Heath, M., Wright, P., Scott, B., Gallego, A. and Andrews, J. (2004) Analysis of the spatial distributions of mature cod (Gadus morhua) and haddock (Melanogrammus aeglefinus) abundance in the North Sea (1980-1999) using generalised additive models. Fish. Res. 70: 17-25.

Hessen, H.J.L. and Rijnsdorp, A.D. (1989) Investigations on egg production and mortality of cod (Gadus morhua L.) and plaice (Pleuronectes platessa L.) in the southern and eastern North Sea in 1987 and 1988. Rapports et Procès-Verbaux des Réunions du Conseil International pour l'Exploration de la Mer, 191: 15-20.

Holley, S.E. and Hydes, D.J. (2002) 'Ferry-Boxes' and data stations for improved monitoring and resolution of eutrophication-related processes: application in Southampton Water UK, a temperate latitude hyper-nutrified estuary. Hydrobiologia 475476: 99-110.

Htun-Han M. (1978) The reproductive biology of the dab Limanda limanda (L.) in the North Sea: Seasonal changes in the ovary. Journal of Fish Biology, 13: 351-359. 
ICES (2004). Manual for the international bottom trawl surveys, rev. VII. International Bottom Trawl Survey Working Group, ICES, Copenhagen. 51 pp. http://www.ices.dk/datacentre/datras/NSIBTSmanualRevVIIdraft.pdf.

Lasker, R., ed (1985) An egg production method for estimating spawning biomass of pelagic fish: application to the northern anchovy (Engraulis mordax) .US Dep. Commer.NOAA Tech. Rep. NMFS 36, 99pp.

Lelièvre, S. (2007) Cartographie des zones de frayères en Mer du Nord (IBTS 2006) et Identification des oeufs de la Manche et de le mer du Nord ( IBTS 2007). Rapport Final (mai 2007), Adrinord, LIMUL, IFREMER, 46 pp.

Lo, N.C.H., Hunter, J.R., Charter, R. (2001) Use of a continuous egg sampler for ichtyoplankton surveys: application to the estimation of daily egg production of Pacific sardine (Sardinops sagax) off California. Fish. Bull., 99: 554-571.

Lund-Hansen, L.C., Poul, S. and Christiansen, C. (1996) Modes of Stratification in a Semi-enclosed Bay at the North Sea-Baltic Sea Transition. Estuar Coast Shelf Sci 42: 45-54.

Mastail, M. and Battaglia, A., (1978) Amélioration de la conservation des pigments du zooplancton, Cons. int. Explor. Mer (CIEM), Comité de l'Océanographie biologique, L : 20.

Munk, P. and Nielsen, J. G. (2005) Egg and larvae of North Sea fishes, biofolia, 215pp.

Munk, P., Fox, C.J., Bolle, L.J., Van Damme, C.J.G., Fossum, P. and Kraus, G. (2009) Spawning of North Sea fishes linked to hydrographic features. Fish. Oceanogr. 18: 458-469.

Ouellet, P. (1997) Characteristics and vertical distribution of Atlantic cod (Gadus morhua) eggs in the northern Gulf of St. Lawrence, and the possible effect of cold water temperature on recruitment, Can. J., Fish. Aquat. Sci., 54: 211-223.

Page, F.H., Frank, K.T. and Thompson, K.R. (1989) Stage dependant vertical distribution of haddock (Melanogrammus aeglefinus) eggs in a stratified water column: observations and model. Can. J., Fish. Aquat. Sci., 46: 55-67.

Pépin, P., Snelgrove, P.V.R, and Carter K.P. (2005) Accuracy and precision of the continuous underway fish egg sampler (CUFES) and bongo nets: a comparison of three species of temperate fish. Fish. Oceanogr. 14: 432-447.

Pépin, P., Curtis, K.A., Snelgrove, P.V.R., de Young, B., and Helbig, J.A. (2007) Optimal estimation of catch by the continous underway fish egg sampler based on a model of the vertical distribution of American plaice (Hippoglossoides platessoides) eggs - ICES J. Mar. Sci., 64: 18-30.

Petitgas, P., Magri, S. and Lazure, P. (2006) One-dimensional biophysical modelling of fish egg vertical distributions in shelf seas, Fish. Oceanogr., 15: 413-428.

Priede, I.G. and Watson, J.J. (1993) An evaluation of the daily egg production method for estimating biomass of Atlantic mackerel (Scomber scombrus). Bull. Mar. Sci. 53:891-911.

R Development Core Team (2005). R: A language and environment for statistical computing. R Foundation for Statistical Computing, Vienna, Austria. ISBN 3-900051-07-0, URL http://www.R-project.org.

Radach, G., Regener, M., Carlotti, F., Kühn, W. and Moll, A. (1993) Modelling water column processes in the North Sea. Phil. Trans. R. Soc. Lond. (A Phys. Sci. Eng.) 343: 509-517.

Rijnsdorp, A.D., Peck, M.A., Engelhard, G.H., Möllmann, C. and Pinnegar, J.K. (2009) Resolving the effect of climate change on fish populations. ICES J. Mar. Sci., 66: 15701583.

Rose GA (1993) Cod spawning on a migration highway in the north-west Atlantic. Nature 366, 458-461.

Russell, F.S. (1976) The Egg and planktonic stages of British marine fishes, Academic Press inc (London) Ltd, 524 pp.

Sakamoto, Y., Ishiguro, M. and Kitagawa, G. (1986) Akaike Information Criterion Statistics. D. Reidel Publishing Company, Dordrecht/Tokyo. 
Scientific Expert Committee for the Fifth International Conference on the Protection of the North Sea (2002), Priority scientific issues for North Sea ecosystem management, Bergen. 2 pp.

Širović, A., Cutter, G.R., Butler, J.L. and Demer, D.A. (2009) Rockfish sounds and their potential use for population monitoring in the Southern California Bight. ICES J. Mar. Sci., 66: 981-990.

Stefánsson, G. (1996). Analysis of groundfish survey abundance data: combining the GLM and delta approaches. ICES J. Mar. Sci., 53: 577-588.

Sundby, S. (1983) A one-dimensional model for the vertical distribution of pelagic fish eggs in the mixed layer. Deep-Sea Res., 30: 645-661.

Taylor, M. I., Fox, C. J., Rico, I. and Rico, C. (2002) Species specific TaqMan probes for simultaneous identification of cod (Gadus morhua L.), haddock (Melanogrammus aeglefinus L.) and whiting (Merlangius merlangus L.). Mol. Ecol. Notes 2: 599-601.

Taylor, N., Fox, C.J., Bolle, L., Dickey-Collas, M., Fossum, P., Kraus, G., Munk, P., Rolf, N., van Damme, C. and Vorbach, M. (2007) Results of the spring 2004 North Sea ichthyoplankton surveys. Report No. 285, International Council for the Exploration of the Sea, Copenhagen.

Thompson, B.M. and Riley, J.D. (1981) Egg and larval development studies in the North Sea cod (Gadus morhua L.). Rapports et Procès-Verbaux des Réunions du Conseil International pour l'Exploration de la Mer;17: 553-559.

Van der Lingen, C.D., Checkley, D., Barange, M., Hutchings, L. And Osgood, K. (1998) Assessing the abundance and distribution of eggs of sardine Sardinops sagax, and round herring, Etrumeus whiteheadi, on the western Agulhas Bak, South Africa, using a continuous, underway fish egg sampler, Fish. Oceanogr., 7: 35-47.

Van der Veer, H.W., Ruardij, P., Van der Berg, A.J. and Ridderinkhof, H. (1998) Impact of interannual variability in hydrodynamic circulation on egg and larval transport of plaice Pleuronectes platessa L. in the southern North Sea, Journal of Sea Research, 38: 39-40.

Webster, R. and Oliver, M. A. (2001) Geostatistics for Environmental Scientists. Wiley, Chichester, $271 \mathrm{pp}$.

Wilcoxon, F. (1945) Individual Comparisons by Ranking Methods. Biometrics Bulletin 1: 80-83.

Zwolinski, J., Mason, E., Peliz, A., Oliveira, P. and Stratoudakis, Y. (2004) Use of the continuous underwater fish egg sampler (CUFES) to study the small scale distribution of sardine (Sardina pilchardus) egg patches. CM 2004/DD:07. 
Figure 1. Locations of stationary CUFES / VET stations (2006 = 66 samples, $2007=68$ samples and $2008=140$ samples).

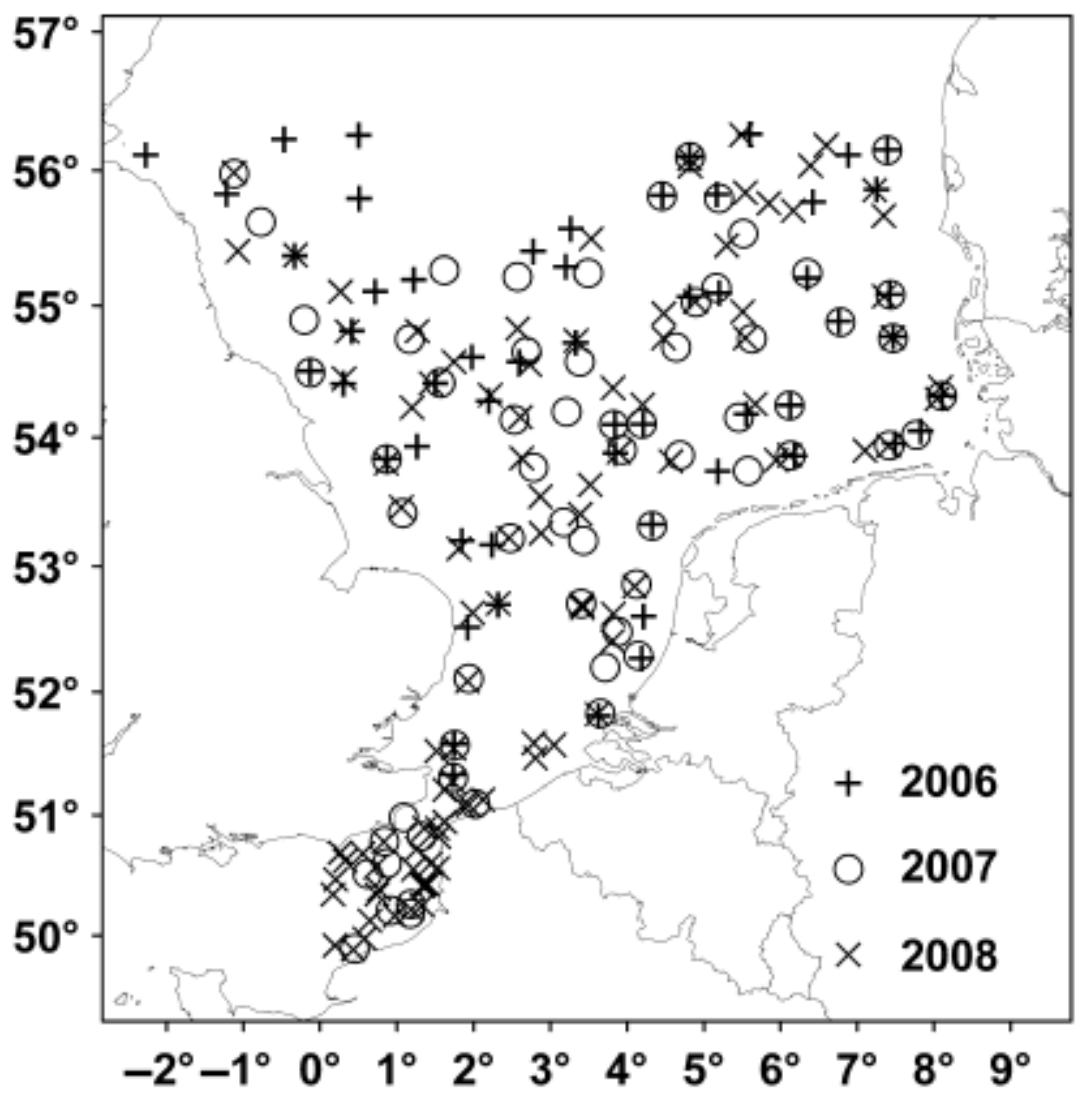


Figure 2. Maps of the environmental parameters used in model development: (a) depth (m), (b) wind speed (knots) in 2006, (c) in 2007, (d) in 2008 and (e) bedstress $\left(\mathrm{N} \mathrm{m}^{-2}\right)$.

(a)

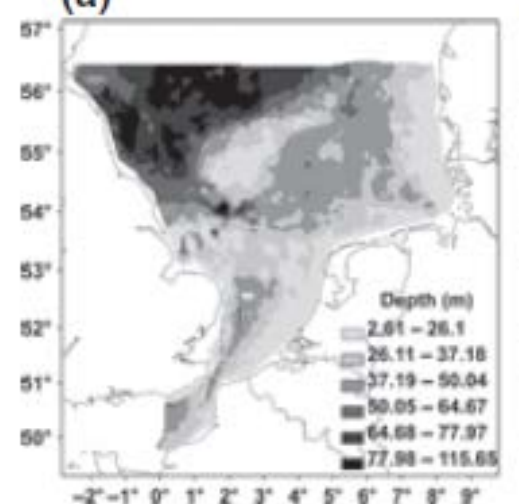

(b)

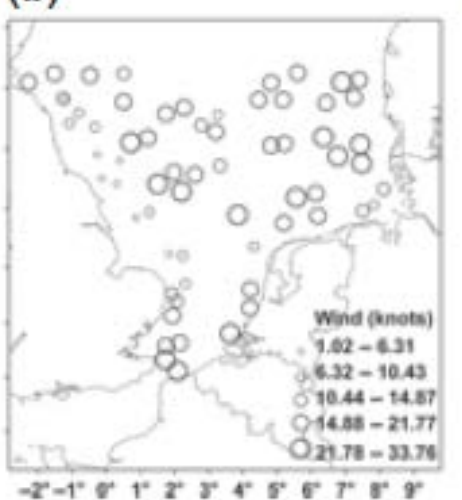

(c)

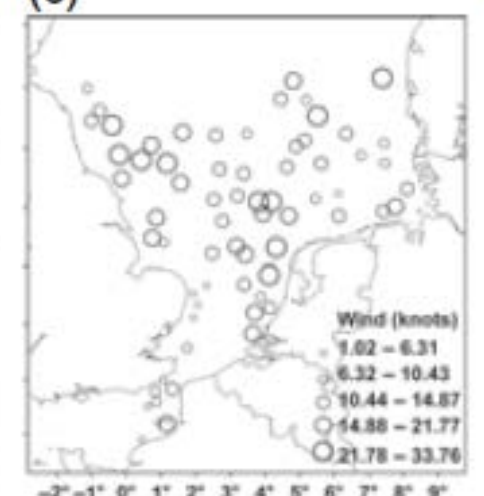

(d)

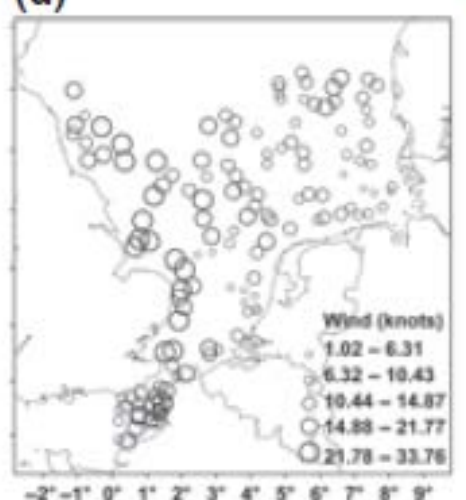

(e)

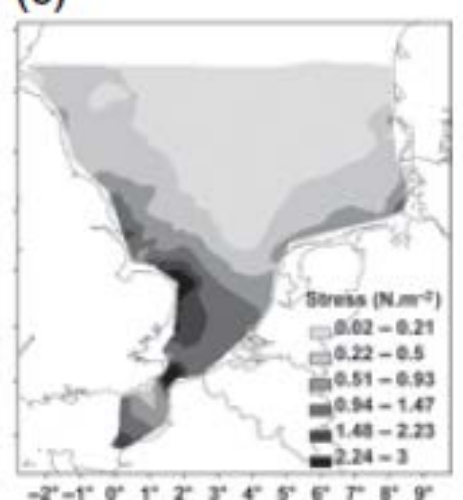


Figure 3. Underway research vessel tracks by year $(2006=947$ samples, $2007=878$ samples and $2008=1050$ samples).

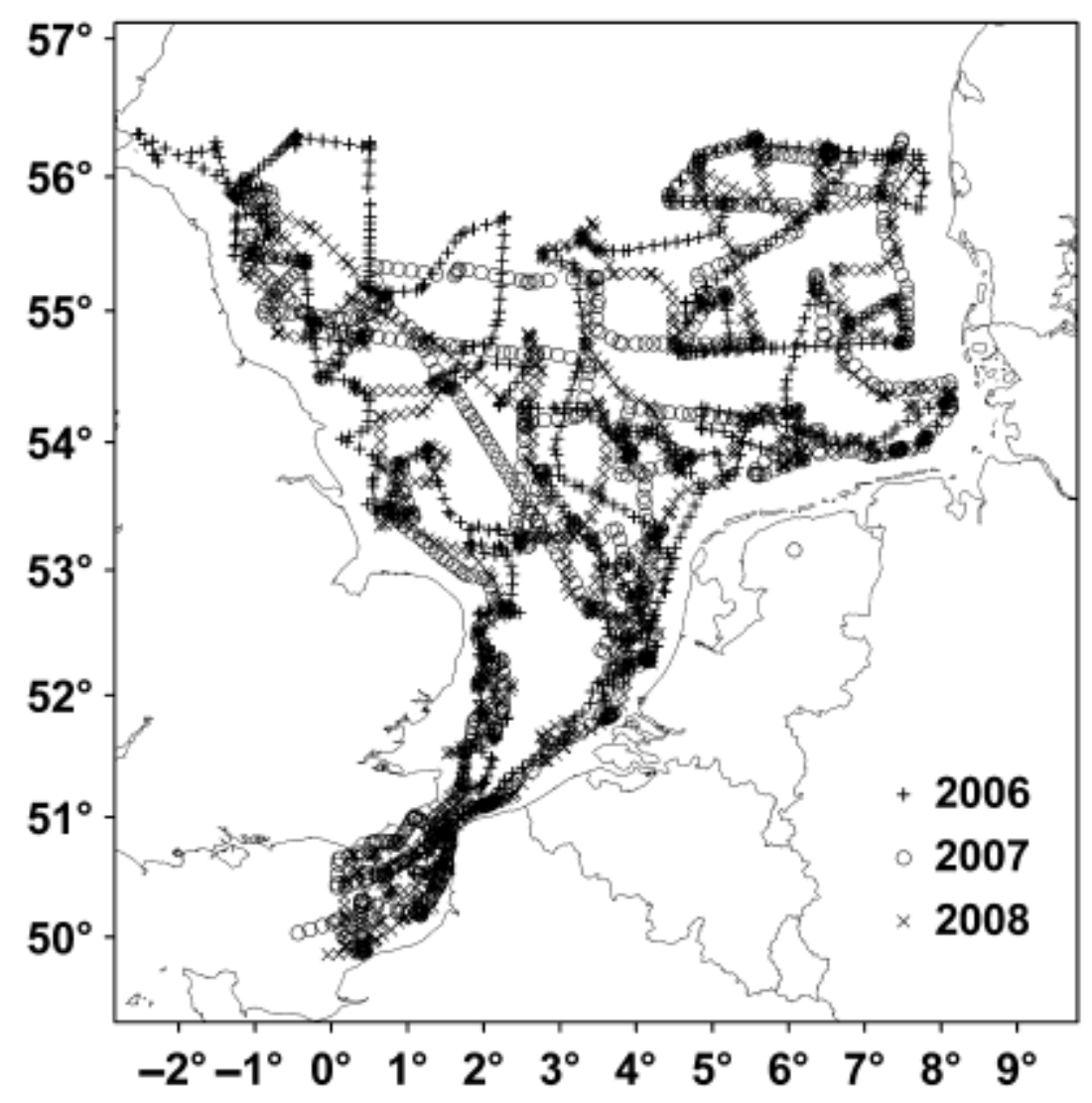


Figure 4. Distribution of dab eggs $\left[\log _{10}(\right.$ eggs +1$)$ per $\left.20 \mathrm{~m}^{3}\right]$ for all developmental stages collected by VET and stationary CUFES from 2006 to 2008. Symbol size was made proportional to egg densities using quantile classes.
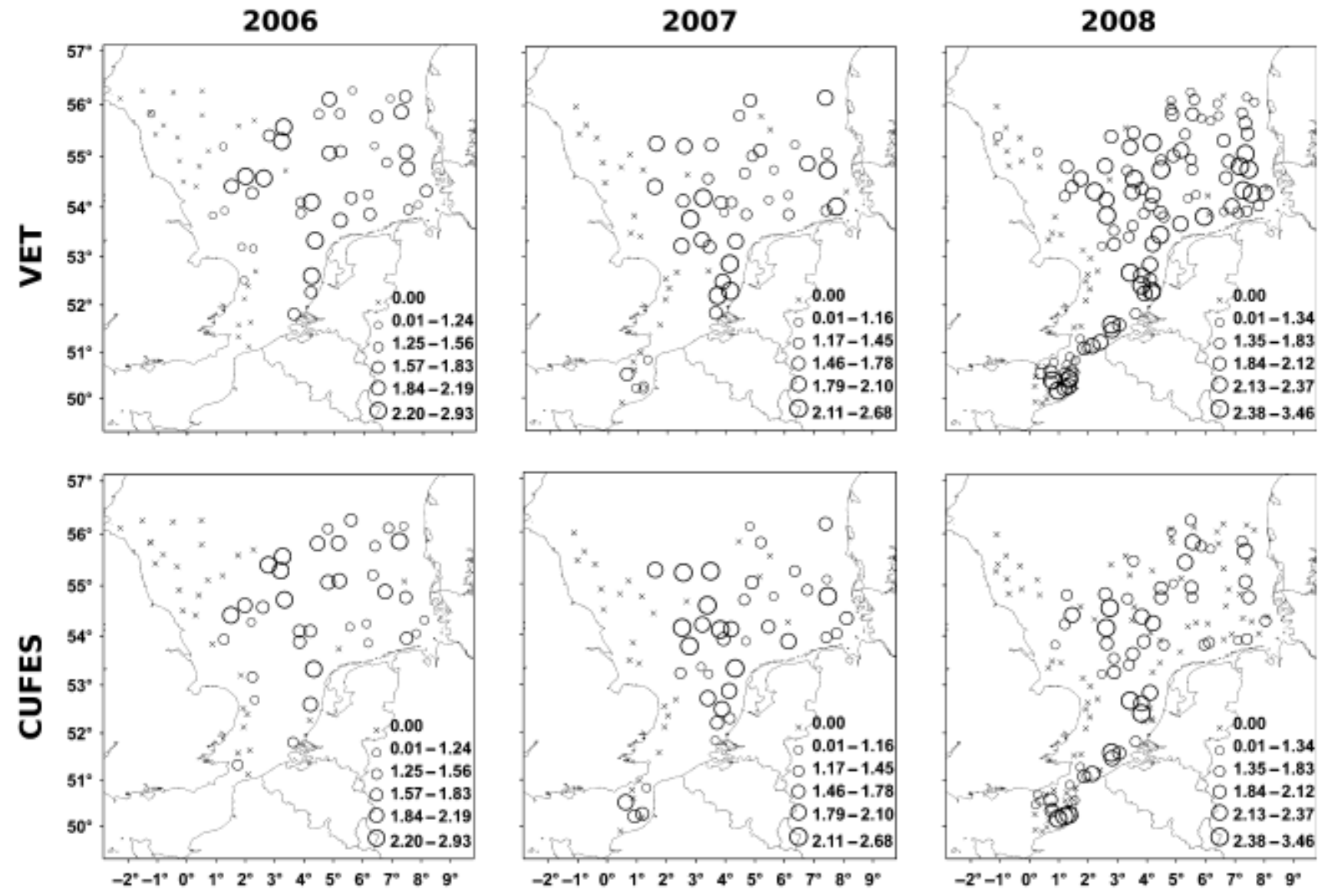
Figure 5. Distribution of cod eggs $\left[\log _{10}(\right.$ eggs +1$)$ per $\left.20 \mathrm{~m}^{3}\right]$ for each developmental stages collected by VET and stationary CUFES from 2006 to 2008. Symbol size was made proportional to egg densities using quantile classes.

Figure 6. Distribution of plaice eggs $\left[\log _{10}(\right.$ eggs +1$)$ per $\left.20 \mathrm{~m}^{3}\right]$ for each developmental stages collected by VET and stationary CUFES from 2006 to 2008. Symbol size was made proportional to egg densities using quantile classes.
Stage 1
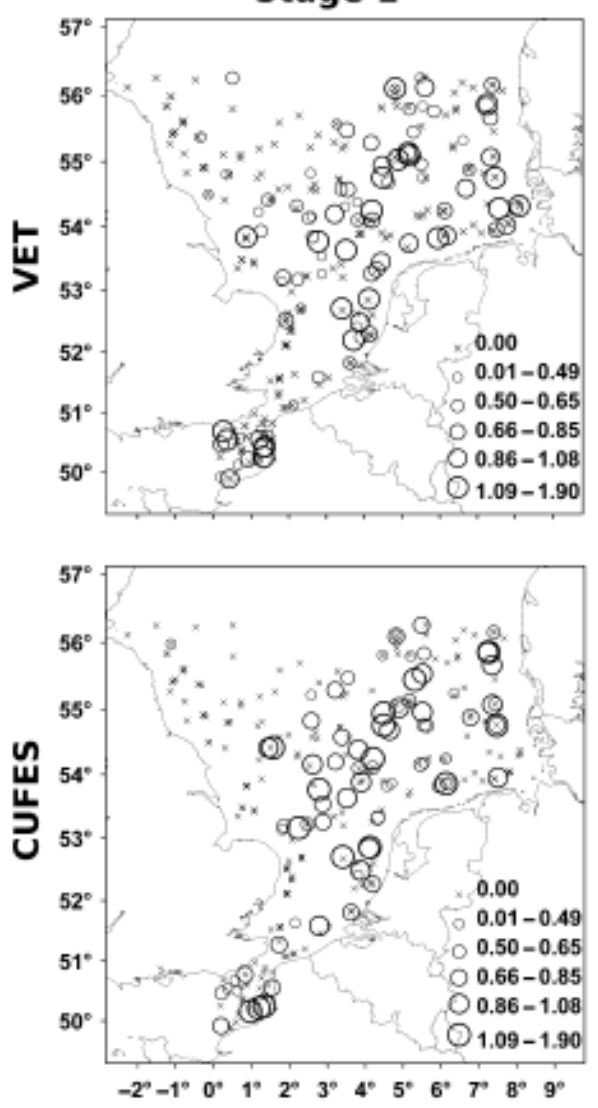

Stage 1
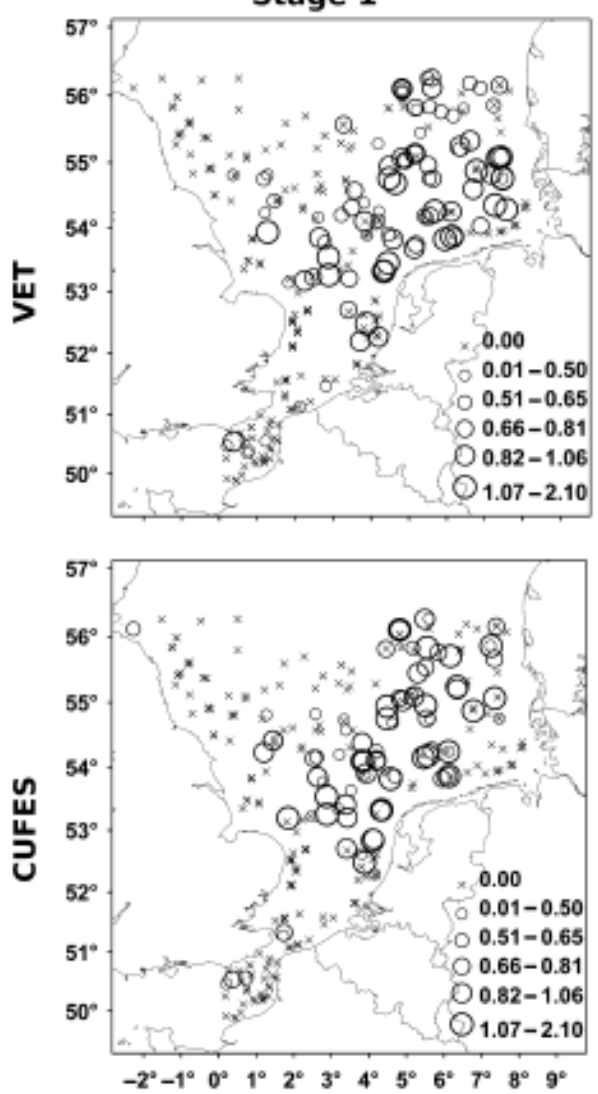

Stage 2 and over
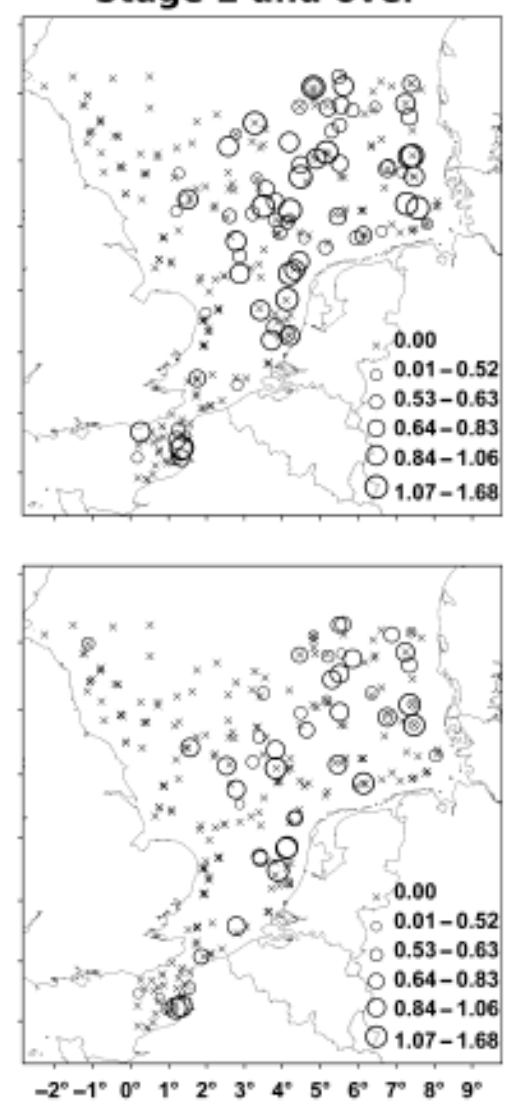

Stage 2 and over
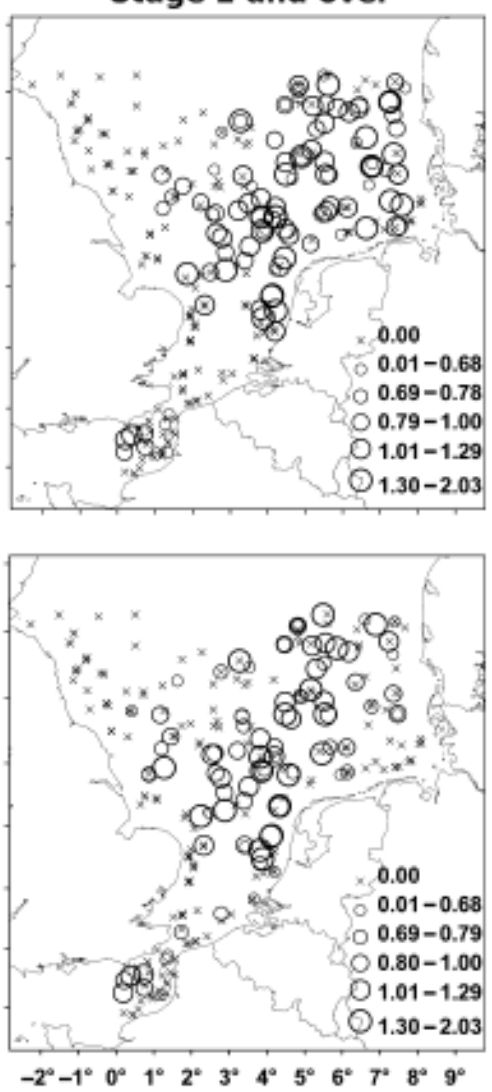
Figure 7. Interpolated distribution maps of dab eggs $\left[\log _{10}(\right.$ eggs +1$)$ per $\left.20 \mathrm{~m}^{3}\right]$ collected by underway CUFES from 2006 to 2008 and the interannual variability, computed as the local standard deviation divided by the maximum density value.
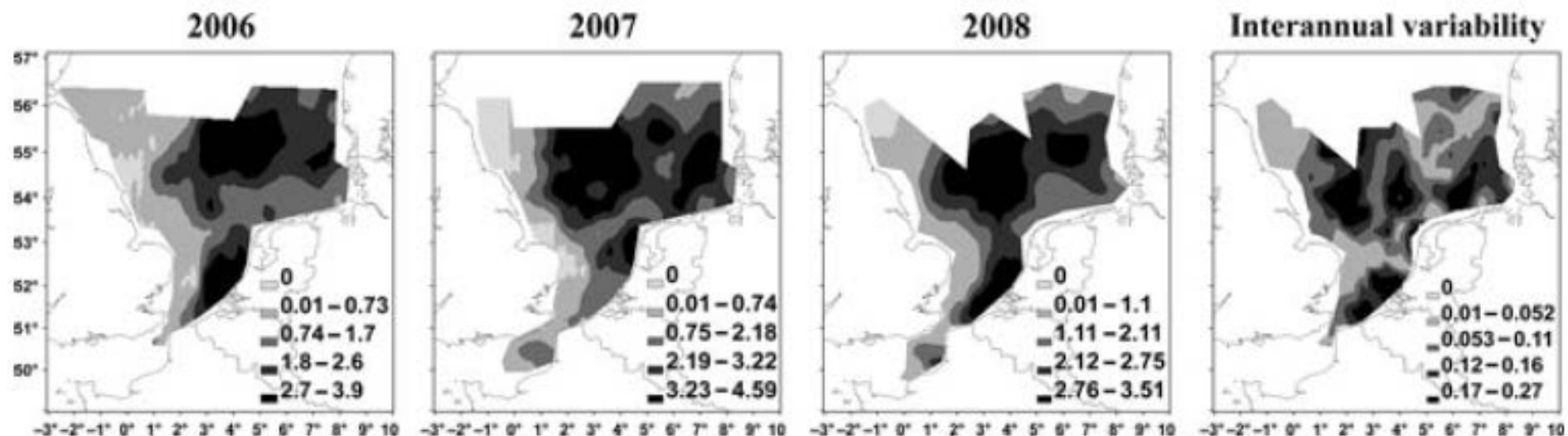
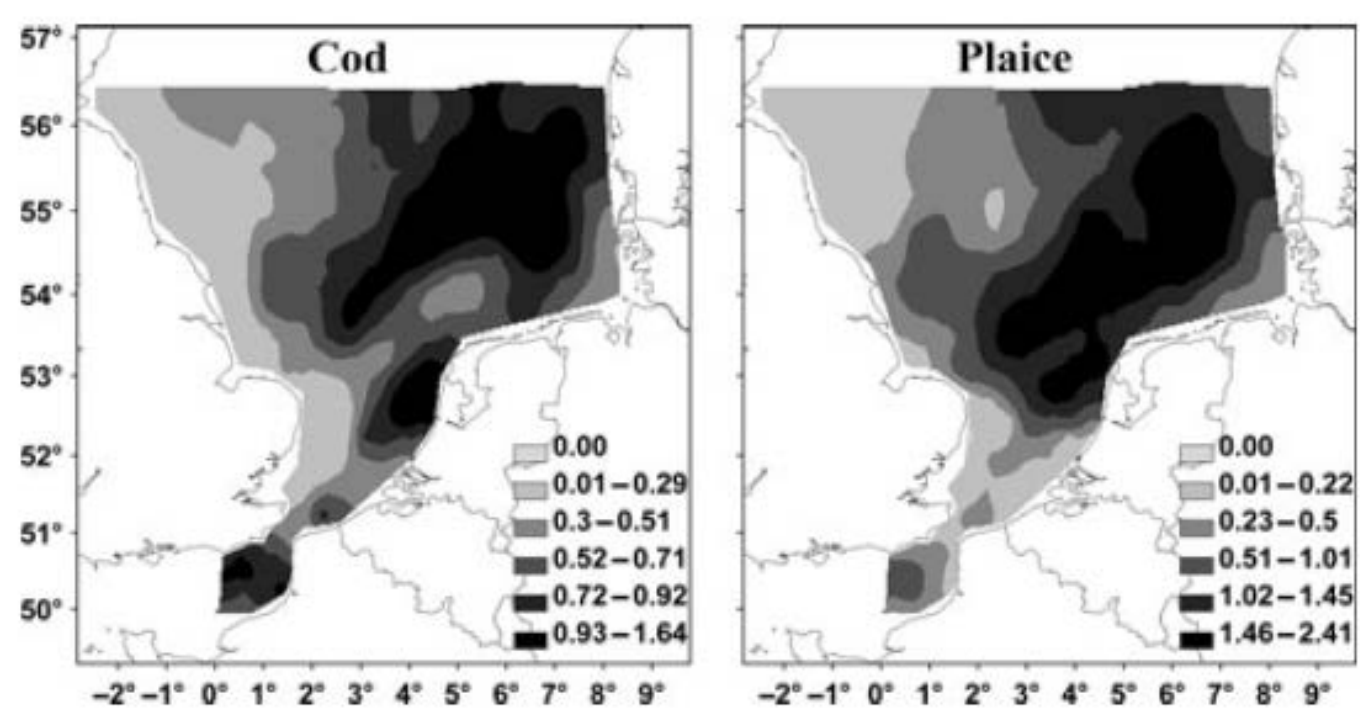

Figure 8. Interpolated distribution maps of cod and plaice eggs $\left[\log _{10}(\right.$ eggs +1$)$ per $20 \mathrm{~m}^{3}$ ] collected by underway CU. FES, averaged over 2006-2008. 
Figure 9. Egg densities from VET samples versus egg densities from stationary CUFES samples $\left[\log _{10}(\right.$ eggs +1$)$ per $\left.20 \mathrm{~m}^{3}\right]$ for (a) dab, (b) cod and (c) plaice. Note that in 56 samples, no eggs were observed in either device.

(a)

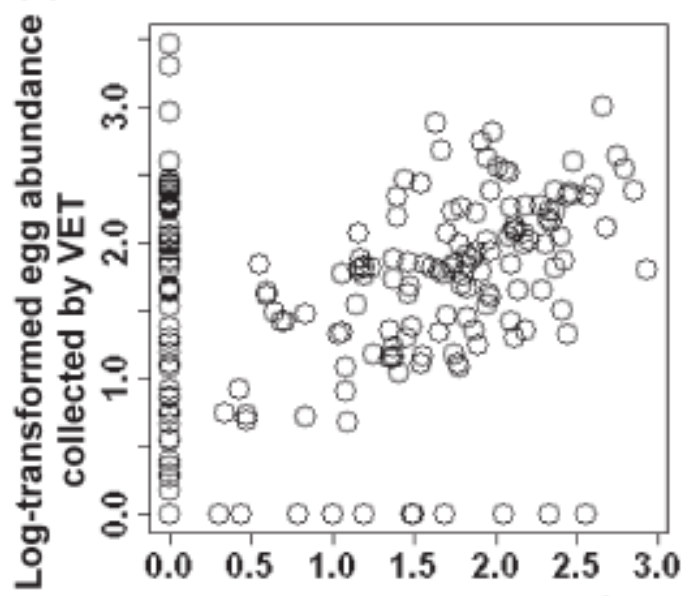

(b)

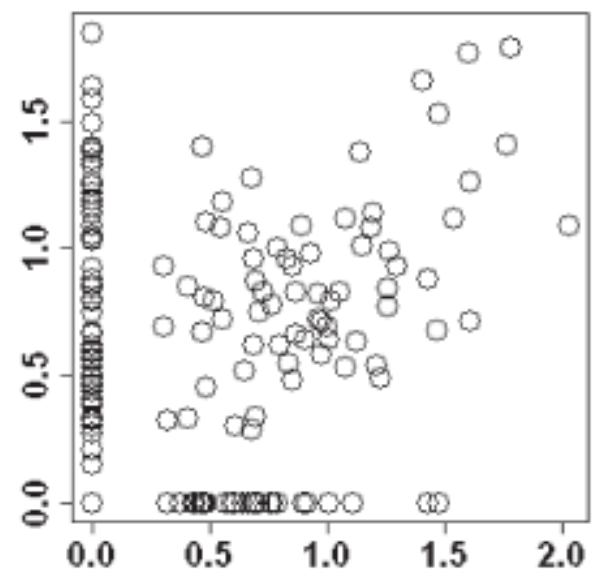

(c)

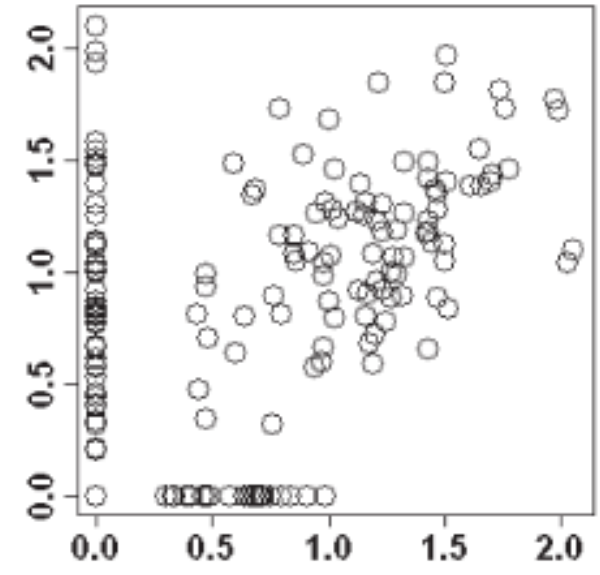

Log-transformed egg abundance collected by CUFES 
Figure 10. Log-transformed egg density errors $\left[\log _{10}\right.$ (egg number +1$)$ for $\left.20 \mathrm{~m}^{3}\right]$ computed as the absolute difference between VET and CUFES observations as a response to local hydrological parameters: (a) wind speed (knots), (b) square of wind speed $\left(\operatorname{knots}^{2}\right)$ (c) log. transformed inverse of depth $\left(\mathrm{m}^{-1}\right)$ and (d) log-transformed bedstress $\left(\mathrm{N} \mathrm{m}^{-2}\right)$.
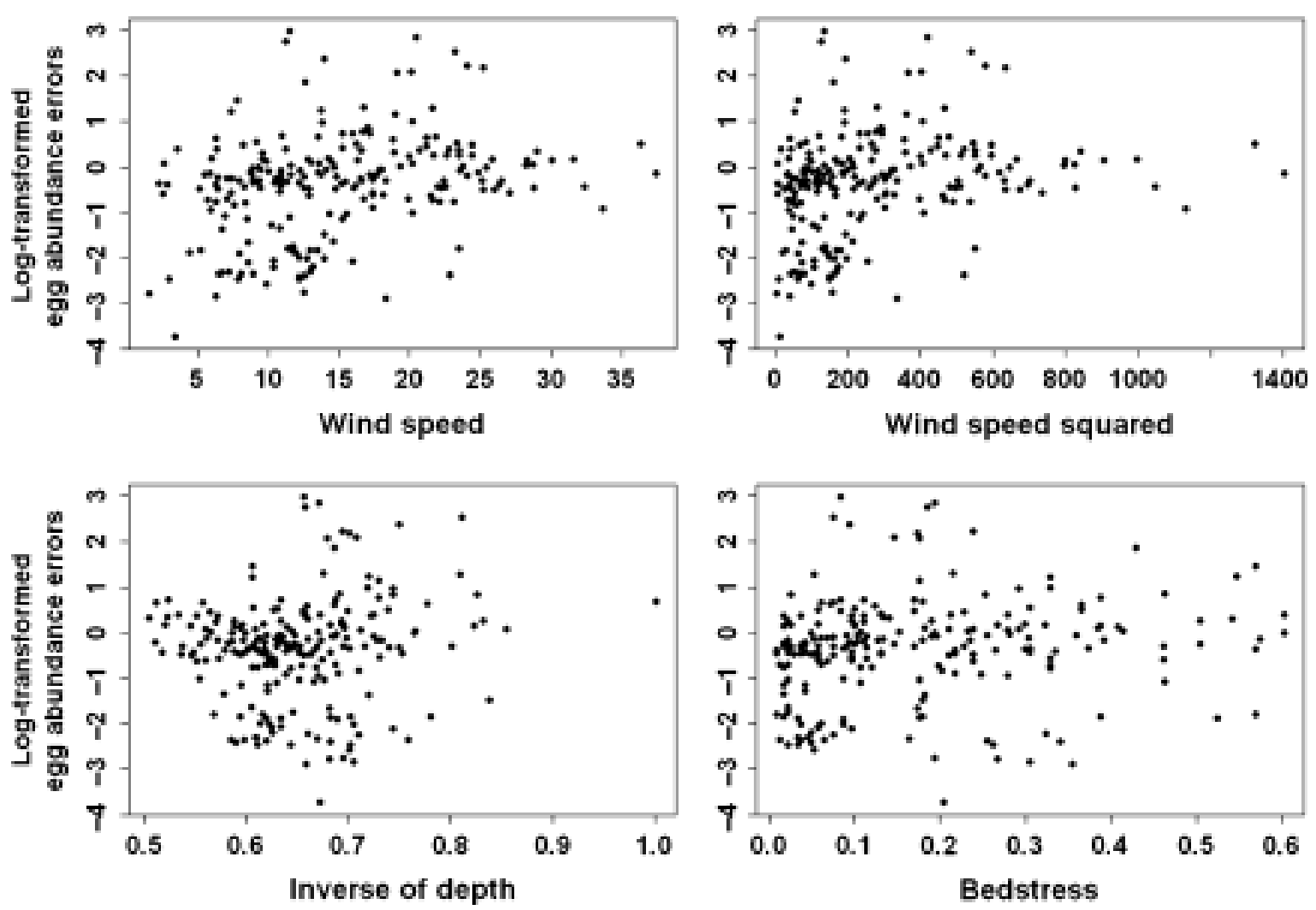
Table 1. Summary of observed temperature and salinity profiles.

\begin{tabular}{|c|c|c|c|c|c|c|c|}
\hline \multirow[b]{2}{*}{ Year (no. of profiles) } & \multirow{2}{*}{$\begin{array}{l}\text { Depth }(\mathrm{m}) \\
\text { Mean } \\
(\mathrm{SD})\end{array}$} & \multicolumn{3}{|c|}{ Temperature $\left({ }^{\circ} \mathrm{C}\right)$} & \multicolumn{3}{|c|}{ Salinity $(\%$ o } \\
\hline & & $\begin{array}{l}\text { Surface } \\
\text { mean (SD) }\end{array}$ & $\begin{array}{l}\text { Bottom } \\
\text { mean (SD) }\end{array}$ & $\begin{array}{l}\text { Difference } \\
\text { mean (SD) }\end{array}$ & $\begin{array}{l}\text { Surface } \\
\text { mean (SD) }\end{array}$ & $\begin{array}{l}\text { Bottom } \\
\text { mean (SD) }\end{array}$ & $\begin{array}{l}\text { Difference } \\
\text { mean (SD) }\end{array}$ \\
\hline $2006(n=66)$ & $41(19)$ & $5.9(1.1)$ & $5.9(1.1)$ & $0.0(0.3)$ & $34.2(1.0)$ & $34.6(0.7)$ & $0.3(0.4)$ \\
\hline $2007(n=68)$ & $36(17)$ & $7.0(0.9)$ & $7.1(0.8)$ & $0.1(0.2)$ & $34.4(1.3)$ & $34.6(0.7)$ & $0.2(0.7)$ \\
\hline $2008(n=140)$ & 27 (14) & $8.1(1.3)$ & $8.4(1.6)$ & $0.3(0.8)$ & $34.4(1.0)$ & $34.2(2.2)$ & $-0.1(1.0)$ \\
\hline
\end{tabular}

Difference is computed as bottom-surface values for each station separately. Mean and standard deviation values were computed over all stations afterwards. 
Table 2. Geostatistical analyses - comparison between stationary VET and CUFES data from 2006 to 2008 ( $n=274)$,

\begin{tabular}{|c|c|c|c|c|c|c|c|c|c|c|c|c|c|}
\hline \multirow[b]{2}{*}{ Species } & \multirow[b]{2}{*}{ Year } & \multicolumn{6}{|l|}{ VET } & \multicolumn{6}{|c|}{ CUFES } \\
\hline & & $\begin{array}{l}\% \\
\text { Trend } \\
\text { fit }\end{array}$ & Model & Nugget & Sill & $\begin{array}{l}\% \\
\text { Spatial } \\
\text { structure }\end{array}$ & Range & $\begin{array}{l}\% \\
\text { Trend } \\
\text { fit }\end{array}$ & Model & Nugget & Sill & $\begin{array}{l}\% \\
\text { Spatial } \\
\text { structure }\end{array}$ & Range \\
\hline Dab & 2006 & 57.7 & Pentaspherical & 0.386 & 3.072 & 80 & 1.72 & 36.2 & Pentaspherical & 1.673 & 1.317 & 63 & 1.96 \\
\hline Plaice & 2006 & - & Circular & 0.856 & 1.592 & 82 & 2.66 & - & Circular & 1.085 & 1.269 & 62 & 1.99 \\
\hline Cod & 2006 & - & Pure nugget & 1.35 & 0 & - & - & - & Pure nugget & 0.7 & 0 & - & - \\
\hline Dab & 2007 & & Circular & 1.571 & 3.012 & 100 & 2.58 & & Circular & 1.952 & 2.976 & 91 & 2.06 \\
\hline Plaice & 2007 & 40.2 & Circular & 0.8867 & 1.523 & 22 & 2.52 & 40.4 & Circular & 0.6242 & 0.8322 & 22 & 2.75 \\
\hline Cod & 2007 & & Circular & 0.433 & 0.789 & 88 & 3.14 & & Circular & 0.979 & 0.917 & 90 & 2.81 \\
\hline Dab & 2008 & - & Circular & 0.3002 & 0.4843 & 64 & 0.8 & - & Circular & 0.7256 & 0.65 & 36 & 0.49 \\
\hline Plaice & 2008 & - & Circular & 0.0241 & 0.0852 & 61 & 0.85 & - & Circular & 0.1527 & 0.3598 & 68 & 0.84 \\
\hline Cod & 2008 & - & Circular & 0.0139 & 0.219 & 49 & 0.56 & - & Circular & 0.2378 & 0.2284 & 27 & 0.68 \\
\hline
\end{tabular}

Trend fit, \% variation explained by quadratic trend and removed before variographic analysis; Model, variogram model used; \% spatial structure, the amount of spatial structuring explained by the variogram; Range, approximate average diameter of patches in decimal degrees of latitude $\left(1^{\circ} \sim 111 \mathrm{~km}\right)$. 
Table 3. Frequency of occurrence of each species in VET and CUFES samples by egg developmental stage $(n=274)$.

\begin{tabular}{|c|c|c|c|c|c|c|}
\hline Species & Stage & $\begin{array}{l}\text { Occurrence } \\
\text { in VET }\end{array}$ & $\begin{array}{l}\text { Occurrence } \\
\text { in CUFES }\end{array}$ & $\begin{array}{l}\text { Co-occurrence } \\
\text { in both } \\
\text { devices }\end{array}$ & $\begin{array}{l}\text { Occurrence } \\
\text { in VET but not } \\
\text { in CUFES }\end{array}$ & $\begin{array}{l}\text { Occurrence in } \\
\text { CUFES but } \\
\text { not in VET }\end{array}$ \\
\hline Cod & \multirow[t]{7}{*}{ All stages } & 0.47 & 0.36 & 0.24 & 0.23 & 0.12 \\
\hline Dab & & 0.68 & 0.51 & 0.46 & 0.22 & 0.04 \\
\hline Plaice & & 0.50 & 0.42 & 0.33 & 0.17 & 0.09 \\
\hline Flounder & & 0.17 & 0.35 & 0.14 & 0.04 & 0.21 \\
\hline Whiting & & 0.36 & 0.30 & 0.19 & 0.17 & 0.11 \\
\hline Am. Plaice & & 0.13 & 0.11 & 0.05 & 0.08 & 0.06 \\
\hline Rocklings & & 0.21 & 0.18 & 0.09 & 0.12 & 0.08 \\
\hline Cod & \multirow[t]{7}{*}{ Stage 1} & 0.36 & 0.30 & 0.19 & 0.17 & 0.12 \\
\hline Dab & & 0.65 & 0.49 & 0.44 & 0.20 & 0.05 \\
\hline Plaice & & 0.35 & 0.30 & 0.20 & 0.15 & 0.10 \\
\hline Flounder & & 0.11 & 0.24 & 0.08 & 0.03 & 0.16 \\
\hline Whiting & & 0.32 & 0.25 & 0.16 & 0.16 & 0.09 \\
\hline Am. Plaice & & 0.16 & 0.12 & 0.04 & 0.10 & 0.06 \\
\hline Rocklings & & 0.09 & 0.09 & 0.07 & 0.06 & 0.05 \\
\hline Cod & \multirow[t]{7}{*}{ Stage $2+$} & 0.28 & 0.19 & 0.10 & 0.18 & 0.09 \\
\hline Dab & & 0.47 & 0.31 & 0.24 & 0.23 & 0.08 \\
\hline Plaice & & 0.40 & 0.35 & 0.25 & 0.15 & 0.09 \\
\hline Flounder & & 0.14 & 0.28 & 0.10 & 0.04 & 0.19 \\
\hline Whiting & & 0.27 & 0.17 & 0.11 & 0.16 & 0.06 \\
\hline Am. Plaice & & 0.07 & 0.03 & 0.02 & 0.05 & 0.01 \\
\hline Rocklings & & 0.11 & 0.10 & 0.05 & 0.06 & 0.05 \\
\hline
\end{tabular}

Am. Plaice, American Plaice. 
Table 4. Summary of fish egg densities and relative proportions of each species in VET and CUFES samples by egg developmental stage $(n=274)$.

\begin{tabular}{|c|c|c|c|c|c|}
\hline \multirow[b]{2}{*}{ Species } & \multirow[b]{2}{*}{ Stage } & \multicolumn{2}{|c|}{ Egg density (for $20 \mathrm{~m}^{3}$ ) } & \multicolumn{2}{|c|}{ Relative proportion } \\
\hline & & $\begin{array}{l}\text { VET } \\
\text { Mean (SD) }\end{array}$ & $\begin{array}{l}\text { CUFES } \\
\text { Mean (SD) }\end{array}$ & $\begin{array}{l}\text { VET } \\
\text { Mean (SD) }\end{array}$ & $\begin{array}{l}\text { CUFES } \\
\text { Mean (SD) }\end{array}$ \\
\hline Cod & All stages & $4.48(9.59)$ & $3.82(10.32)$ & $0.07(0.18)$ & $0.05(0.14)$ \\
\hline $\mathrm{Dab}$ & & $95.32(244.53)$ & $54.51(114.19)$ & $0.46(0.36)$ & $0.34(0.36)$ \\
\hline Plaice & & $8.68(16.65)$ & $7.36(16.09)$ & $0.10(0.17)$ & $0.11(0.21)$ \\
\hline Flounder & & $8.66(37.88)$ & $24.55(81.69)$ & $0.05(0.13)$ & $0.11(0.21)$ \\
\hline Whiting & & $15.69(49.06)$ & $8.45(28.86)$ & $0.08(0.16)$ & $0.07(0.18)$ \\
\hline Am. Plaice & & $0.77(2.69)$ & $0.55(2.44)$ & $0.01(0.05)$ & $0.01(0.08)$ \\
\hline Rocklings & & $0.95(2.59)$ & $0.96(3.78)$ & $0.02(0.07)$ & $0.02(0.09)$ \\
\hline Cod & Stage 1 & $2.48(5.79)$ & $2.58(8.06)$ & $0.08(0.20)$ & $0.06(0.15)$ \\
\hline $\mathrm{Dab}$ & & $54.29(135.31)$ & $40.53(90.72)$ & $0.62(0.35)$ & $0.49(0.39)$ \\
\hline Plaice & & $2.78(9.18)$ & $2.69(6.33)$ & $0.08(0.16)$ & $0.08(0.18)$ \\
\hline Flounder & & $5.25(26.81)$ & $14.86(61.16)$ & $0.06(0.18)$ & $0.12(0.25)$ \\
\hline Whiting & & $8.27(27.60)$ & $5.41(19.96)$ & $0.10(0.19)$ & $0.09(0.21)$ \\
\hline Am. Plaice & & $0.39(1.64)$ & $0.31(1.32)$ & $0.01(0.04)$ & $0.01(0.08)$ \\
\hline Rocklings & & $0.58(1.65)$ & $0.61(2.55)$ & $0.03(0.10)$ & $0.03(0.13)$ \\
\hline Cod & Stage $2+$ & $2.00(5.65)$ & $1.21(3.40)$ & $0.06(0.15)$ & $0.04(0.10)$ \\
\hline $\mathrm{Dab}$ & & $41.02(131.92)$ & $13.98(37.86)$ & $0.46(0.36)$ & $0.31(0.34)$ \\
\hline Plaice & & $5.90(12.18)$ & $4.66(12.02)$ & $0.20(0.29)$ & $0.23(0.32)$ \\
\hline Flounder & & $3.41(13.99)$ & $9.65(27.19)$ & $0.08(0.21)$ & $0.22(0.32)$ \\
\hline Whiting & & $7.42(24.12)$ & $2.97(11.75)$ & $0.10(0.20)$ & $0.06(0.15)$ \\
\hline Am. Plaice & & 0.38 (1.93) & $0.23(1.82)$ & $0.02(0.08)$ & $0.01(0.07)$ \\
\hline Rocklings & & $0.38(1.41)$ & $0.31(1.40)$ & $0.03(0.13)$ & $0.01(0.09)$ \\
\hline
\end{tabular}

Am. Plaice, American Plaice. 
Table 5. Binomial GLM models summary showing model regression parameters, their significance levels and model adjusted $R^{2}$. These results enable prediction of the probability of VET egg density from the occurrence of eggs in CUFES.

\begin{tabular}{|c|c|c|c|c|c|c|c|c|c|c|c|c|c|}
\hline \multirow[b]{3}{*}{ Gadus morhua } & & & \multicolumn{11}{|c|}{ GLM binomial } \\
\hline & \multicolumn{2}{|c|}{$\begin{array}{l}\text { Intercept } \\
(P \text {-value })\end{array}$} & \multicolumn{2}{|c|}{$\begin{array}{l}\text { CUFES } \\
\text { ( } P \text {-value })\end{array}$} & \multicolumn{2}{|c|}{$\begin{array}{l}\text { Wind } \\
\text { (P-value) }\end{array}$} & \multicolumn{2}{|c|}{$\begin{array}{l}\text { Wind }{ }^{2} \\
\text { (P-value) }\end{array}$} & \multicolumn{2}{|c|}{$\begin{array}{l}\text { 1/depthT } \\
\text { (P-value) }\end{array}$} & \multicolumn{2}{|c|}{$\begin{array}{l}\text { StressT } \\
\text { (P-value) }\end{array}$} & \multirow{2}{*}{$\begin{array}{l}\begin{array}{l}\text { Adjusted } \\
R^{2}\end{array} \\
0.09\end{array}$} \\
\hline & -0.37 & $\bullet$ & 1.46 & **** & & & & & & & -1.48 & NS & \\
\hline Limanda limanda & -7.96 & $* * *$ & 2.43 & $* * * *$ & & & 0.00 & $* *$ & 15.29 & $* * *$ & -7.32 & $* * *$ & 0.38 \\
\hline Pleuronectes platessa & -2.62 & $*$ & 2.11 & $* * * *$ & & & & & 4.42 & $*$ & -6.57 & $* * *$ & 0.26 \\
\hline Platichtys flesus & -6.79 & $* * *$ & 2.29 & $* * *$ & & & & & 6.86 & $*$ & -3.02 & $\bullet$ & 0.21 \\
\hline Merlangius merlangus & -3.55 & $* *$ & 1.68 & $* * * *$ & -0.04 & • & & & 4.59 & $*$ & & & 0.12 \\
\hline Hippoglossoides platessoides & 1.03 & NS & 1.34 & $* *$ & -0.09 & $*$ & & & & & -23.27 & $* * *$ & 0.32 \\
\hline Lotidae & -0.96 & $*$ & 1.73 & $* * *$ & -0.06 & $*$ & & & & & & & 0.11 \\
\hline
\end{tabular}

Wind speed is in kt, depth $(\mathrm{m})$ and $\left(\mathrm{N} \mathrm{m}^{-2}\right)$ were $\log$-transformed (depthT and stress $\mathrm{T}$ ), the inverse of depth was preferred (1/depthT), NS $P>0.05,{ }^{*} P=0.05, * P<0.05, * * P<0.01, * * * P<0.001$. 
Table 6. Gaussian GLM models summary showing model regression parameters, the ir significance levels and model adjusted $R^{2}$. These results enable prediction of the probability of VET egg density from the occurrence of eggs in CUFES.

\begin{tabular}{|c|c|c|c|c|c|c|c|c|c|c|c|c|}
\hline \multirow[b]{3}{*}{ Gadus morhua } & & & \multicolumn{10}{|c|}{ GLM binomial } \\
\hline & \multicolumn{2}{|c|}{$\begin{array}{l}\text { Intercept } \\
\text { ( } P \text {-value })\end{array}$} & \multicolumn{2}{|c|}{$\begin{array}{l}\text { CUFES } \\
\text { ( } P \text {-value })\end{array}$} & \multicolumn{2}{|c|}{$\begin{array}{l}\text { Wind } \\
\text { (P-value) }\end{array}$} & \multicolumn{2}{|c|}{$\begin{array}{l}\text { Wind }{ }^{2} \\
\text { (P-value) }\end{array}$} & \multicolumn{2}{|c|}{$\begin{array}{l}\text { 1/depthT } \\
\text { ( } P \text {-value) }\end{array}$} & $\begin{array}{l}\text { Stress T } \\
\text { ( } P \text {-value })\end{array}$ & \multirow{2}{*}{$\begin{array}{l}\text { Adjusted } \\
R^{2} \\
0.22\end{array}$} \\
\hline & -0.17 & NS & 0.37 & $* * *$ & & & & & 1.05 & $\bullet$ & & \\
\hline Limanda limanda & -0.73 & $\bullet$ & 0.52 & $* * *$ & & & & & 2.46 & $* * *$ & & 0.41 \\
\hline Pleuronectes platessa & -0.20 & NS & 0.45 & $* * *$ & -0.05 & $*$ & 0.00 & $* *$ & 1.74 & $* *$ & & 0.33 \\
\hline Platichtys flesus & 0.28 & NS & 0.39 & $* * *$ & & & 0.00 & $* *$ & & & 1.42 & 0.35 \\
\hline Merlangius merlangus & -0.90 & & 0.78 & NS & & & & & 1.83 & $\bullet$ & & 0.58 \\
\hline $\begin{array}{l}\text { Hippoglossoides } \\
\text { platessoides }\end{array}$ & -1.57 & NS & 0.54 & $*$ & & & & & 3.29 & NS & & 0.46 \\
\hline Lotidae & -0.78 & NS & 0.47 & $* *$ & & & & & 1.79 & $\bullet$ & & 0.43 \\
\hline
\end{tabular}

Wind speed is in $\mathrm{kt}$, depth $(\mathrm{m})$ and $\left(\mathrm{N} \mathrm{m}^{-2}\right)$ were $\log$-transformed (depthT and stress $\left.\mathrm{T}\right)$, the inverse of depth was preferred (1/depthT), NS $P>0.05,{ }^{*} P=0.05, * P<0.05, * * P<0.01$, **** $P<0.001$. 
Table 7. Delta model evaluation summary: Spearman correlation, Wilcoxon rank test and Adjusted $R^{2}$ results. These results enable evaluation of the ability of the delta models to predict VET egg densities from CUFES densities.

\begin{tabular}{|c|c|c|c|c|c|}
\hline & \multicolumn{5}{|c|}{ Delta model } \\
\hline & \multicolumn{2}{|c|}{$\begin{array}{l}\text { Spearman } \\
\text { correl. }\end{array}$} & \multicolumn{2}{|c|}{$\begin{array}{l}\text { Wilcoxon rank } \\
\text { test }\end{array}$} & \multirow{2}{*}{$\begin{array}{l}\text { Adjusted } \\
R^{2}\end{array}$} \\
\hline & $\rho$ & $P$-values & V & $P$-values & \\
\hline Cod & 0.4 & ***** & 9739 & ***** & 0.48 \\
\hline Dab & 0.5 & $* * * *$ & 15173 & ******* & 0.59 \\
\hline Plaice & 0.6 & $* * *$ & 9819 & $* * * *$ & 0.63 \\
\hline Flounder & 0.48 & $* * * *$ & 3312 & NS & 0.22 \\
\hline Whiting & 0.43 & $* * *$ & 6552 & $* * * *$ & 0.42 \\
\hline Am. plaice & 0.37 & $* * *$ & 1040 & $* * *$ & 0.31 \\
\hline Rockling species & 0.37 & $* * * *$ & 2711 & $* * * *$ & 0.3 \\
\hline
\end{tabular}

Am. Plaice, American Plaice; $P>0.05$, **** $P<0.001$. 